NBER WORKING PAPER SERIES

\title{
SLUM CLEARANCE AND URBAN RENEWAL IN THE UNITED STATES
}

\author{
William J. Collins \\ Katharine L. Shester \\ Working Paper 17458 \\ http://www.nber.org/papers/w17458 \\ NATIONAL BUREAU OF ECONOMIC RESEARCH \\ 1050 Massachusetts Avenue \\ Cambridge, MA 02138 \\ September 2011
}

Arielle Samet and Mike Moody provided excellent research assistance. The authors gratefully acknowledge helpful insights from anonymous referees, Martha Bailey, Richard Bingham, Leah Platt Boustan, Leah Brooks, Linda Carter, Price Fishback, Carola Frydman, Robert Groberg, Kei Hirano, Shawn Kantor, Robert Margo, Greg Niemesh, and John Wallis; assistance from the staff at the National Archives in College Park, Maryland; and suggestions from seminar participants at the University of California at Merced, University of Arizona, University of Michigan, Harvard University, University of Tennessee, the Economic History Association Meetings (2009), Allied Social Science Associations Meetings (2009), Southern Economic Association Meetings (2009) and the Econometric Society World Congress (2010). Part of this research was supported by Vanderbilt's Kirk Dornbush Research Assistantship and Douglas Grey Funds. The views expressed herein are those of the authors and do not necessarily reflect the views of the National Bureau of Economic Research.

NBER working papers are circulated for discussion and comment purposes. They have not been peerreviewed or been subject to the review by the NBER Board of Directors that accompanies official NBER publications.

(C) 2011 by William J. Collins and Katharine L. Shester. All rights reserved. Short sections of text, not to exceed two paragraphs, may be quoted without explicit permission provided that full credit, including (C) notice, is given to the source. 
Slum Clearance and Urban Renewal in the United States

William J. Collins and Katharine L. Shester

NBER Working Paper No. 17458

September 2011, Revised November 2012

JEL No. H7,K0,N12,R0

\begin{abstract}
$\underline{\text { ABSTRACT }}$
We study the local effects of a federal program that helped cities clear areas for redevelopment, rehabilitate structures, complete city plans, and enforce building codes. We use an instrumental variable strategy to estimate the program's effects on city-level measures of income, property values, employment and poverty rates, and population. The estimated effects on income, property values, and population are positive and economically significant. They are not driven by changes in demographic composition. Estimated effects on poverty reduction and employment are positive but imprecise. The results are consistent with a model in which local productivity is enhanced.
\end{abstract}

\author{
William J. Collins \\ Department of Economics \\ Vanderbilt University \\ VU Station B \#351819 \\ 2301 Vanderbilt Place \\ Nashville, TN 37235-1819 \\ and NBER \\ william.collins@vanderbilt.edu \\ Katharine L. Shester \\ Washington and Lee University \\ Holekamp Hall \\ Lexington, Virginia 24450 \\ shesterk@wlu.edu
}


This paper develops new evidence on the local economic effects of an ambitious and highly controversial program of slum clearance and urban redevelopment that was undertaken in the United States after World War II. Title I of the Housing Act of 1949 aimed to revitalize American central cities by offering federal subsidies for locally planned redevelopment projects. When the subsidies were combined with powers of eminent domain delegated by state governments, local agencies were able to assemble, clear, and then sell parcels of land in "blighted" urban areas for redevelopment. Cities also received funding for planning, code enforcement, and the rehabilitation of structures and neighborhoods. By the time new funding for the program ended in 1974, local authorities had been awarded federal support for more than 2,100 distinct urban renewal projects with grants totaling approximately \$53 billion (in 2009 dollars), as well as smaller sums for related activities (U.S. Department of Housing and Urban Development (HUD) 1974a, 15). ${ }^{1}$

Although the U.S. urban renewal program ended nearly 40 years ago, the economic problems that it attempted to address, the basic policy tools that were employed, and the ensuing conflict over its implementation are not specific to American cities in this period. ${ }^{2}$ Policymakers in many countries struggle to manage urban growth and modernization while balancing demands for individual property rights, historic preservation, and housing for the poor (Priemus and Metselaar 1993, Mukhija 2001, Zhang and Fang 2004, Field and Kremer 2005, Wines and Ansfield 2010). The use of eminent domain and subsidies to facilitate private redevelopment is still highly controversial in the United States, as demonstrated by the sharp public response to the U.S. Supreme Court's 2005 decision in Kelo v. City of New London (Somin 2009). ${ }^{3}$ Arguments favoring policies that facilitate urban redevelopment typically claim that private agents face

\footnotetext{
${ }^{1}$ The sum of federal grants for projects understates the magnitude of resources associated with the program's operation for several reasons: the public funds typically just cleared the way for redevelopment, which entailed an unknown but large amount of subsequent investment; the grants covered only a portion of the costs for planning, acquiring, and clearing land; and the range of urban renewal "programs" was broader than specific "projects.” After 1974, federal funds were channeled to cities under the Community Development Block Grant (CDBG) program. See Galster et al. (2004) on CDBG.

${ }^{2}$ The program was originally characterized as "slum clearance" and "urban redevelopment," but for brevity and consistency with later terminology, we refer to it as "urban renewal." The Housing Act of 1937 initiated federal funding for public housing and encouraged slum clearance. It was modest in scale compared to urban renewal efforts under the Housing Act of 1949.

${ }^{3}$ In Kelo the issue at hand was whether taking property for private redevelopment constitutes a valid public use, which echoed earlier concerns with the urban renewal program. The Supreme Court's decision in Berman v. Parker (1954) is highly relevant in this context.
} 
prohibitive transactions costs in assembling parcels of land that could be put to more productive use and that positive externalities from redevelopment may benefit a city broadly. Whether such benefits accrue in practice is a difficult and important empirical question.

Much has been written about the U.S. urban renewal program, but surprisingly few studies have collected and analyzed pertinent data. ${ }^{4}$ Most of the literature is overwhelmingly negative in its assessment, decrying the disproportionate impact on poor residents, the use of eminent domain to trump private property rights, the destruction of cohesive neighborhoods, the loss of historic buildings, the economic rationale for the program, and the aesthetics of the new structures (inter alia Jacobs 1961, Anderson 1964, Gans 1965, Wilson 1966, von Hoffman 2000, Gotham 2001). Unfortunately, econometric evaluation of the program’s effects on local economies is nearly absent from the historical record, and therefore answers to fundamental questions about what the program accomplished are unknown.

We exploit the substantial degree of cross-place variation in urban renewal activity to estimate the program's effects on city-level economic outcomes. The paper makes three main advances toward a better understanding of the program's effects. First, because cities planned and undertook the projects, selection is likely to bias ordinary least squares estimates; therefore, our empirical strategy features an instrumental variable that legally constrained cities' ability to participate in the program. Second, we compile and examine a new dataset for all cities with more than 25,000 residents in 1950 and 1980, thereby spanning the entire period during which the program operated and the recipients of the vast majority of urban renewal funding. Since urban renewal projects often took several years to plan and execute, spanning a long period, including a number of years after the program's end, is important. Third, to the extent that urban renewal affected city-level outcomes, we examine whether such effects worked primarily through the displacement of residents with relatively low levels of human capital (i.e., changes in population composition) or, alternatively, through channels consistent with economic growth. We discuss these findings in the context of a simple Rosen-Roback framework of spatial equilibrium (Rosen 1979, Roback 1982).

\footnotetext{
${ }^{4}$ Bingham (1975) is closest in spirit to our work. He uses city-level data from 1960 and 1970 to describe the distribution of urban renewal funds and correlations between housing market variables and urban renewal grants. More recently, Rossi-Hansberg, Sarte, and Owens (2010) identified sizable land value effects from Richmond's "Neighborhoods in Bloom” program, which, like urban renewal, targeted specific areas for concentrated program interventions.
} 
The results suggest a far less dismal legacy for the U.S. urban renewal program than is commonly portrayed. It appears that cities that were allowed to engage more actively in urban renewal posted better outcomes in 1980 than they otherwise would have in terms of property value, income, and population growth. Moreover, these results were not achieved by merely pushing residents with low human capital levels out of the city. We caution that the results do not imply that Title I was the best way to provide aid to central cities, nor do they imply that the dislocation costs for displaced residents and businesses were relatively unimportant. ${ }^{5}$ In practice, these costs and their perceived unfairness hastened the program's demise.

\section{Background}

\section{A. A Brief History of American Slum Clearance and Urban Renewal}

In the aftermath of the Great Depression and World War II, housing and urban issues rose to the top of the U.S. domestic policy agenda, and the elimination of slums and redevelopment of central cities became prominent objectives (Gelfand 1975, Teaford 1990, Fogelson 2001). As early as 1941, the Federal Housing Administration (FHA) and economists Guy Greer and Alvin Hansen published plans for federally-aided slum clearance and urban redevelopment that had many similarities to subsequent legislation (Foard and Fefferman 1960). Proponents of urban renewal believed that blight was rooted in powerful negative externalities and was therefore "contagious." They also argued that transaction costs inhibited the assembly and redevelopment of land in central cities by private enterprise, that city governments had neither the legal nor the financial resources to undertake large-scale clearance and renewal efforts, and that the problems associated with slums were a national policy priority (Slayton 1966).

In 1949, Congress authorized the Housing and Home Finance Agency (HHFA) to assist locally planned urban renewal projects with grants of two-thirds (or in some cases three-fourths) of the net project cost to the city, where the net cost was defined as the difference between the total cost of acquiring and clearing properties and the income received from selling the cleared land. The original Act emphasized clearance and redevelopment of a "predominantly residential”

\footnotetext{
${ }^{5}$ A full cost-benefit analysis of the program is beyond the scope of this paper. See Rothenberg (1967) for a discussion of the difficulties such an undertaking would entail. Glaeser and Gottlieb (2008) address the potential pitfalls of public policies that target specific places.
} 
character, but subsequent legislation widened the program's scope to include more rehabilitation and conservation efforts, made exceptions for projects that were not predominantly residential (such as hospital and university expansions), and added emphasis on city-wide planning and code enforcement.

The grant application and project execution processes changed over time, but a typical chronology started with the creation of a Local Public Agency (LPA) that was “enabled” under state legislation to undertake urban renewal activities and to exercise eminent domain powers. The LPA would identify an urban renewal area (typically characterized by "blight” or signs of deterioration), hold public hearings, seek approval from the local government (e.g., city council), and then seek approval from HHFA (or later HUD) to proceed with specific project planning within that area. The project plans would include detailed information on current and proposed land use, changes in streets and utilities, aid for displaced residents and businesses, and estimates of the costs. Once approved, a combination of federal loans and grants would allow the project to proceed. ${ }^{6}$ Projects often took several years to complete, and the slow pace of progress was a continual source of frustration.

As of June 30, 1966, the last date on which detailed data are available, approved projects had cleared (or intended to clear) over 400,000 housing units, forcing the relocation of over 300,000 families, just over half of whom were nonwhite. ${ }^{7}$ The proposed clearance areas included nearly 57,000 total acres (90 square miles), of which about 35 percent was proposed for residential redevelopment, 27 percent for streets and public rights-of-way, 15 percent for industrial use, 13 percent for commercial use, and 11 percent for public or "semi-public” use (HUD 1966, 9).

The urban renewal program began with fairly broad political support, but it became increasingly controversial with time. Although national publications, such as Time Magazine (Nov. 6, 1964), trumpeted the program’s accomplishments well into the 1960s, and proponents responded strongly to the critics and clarified the program's goals and lessons-learned (Groberg

\footnotetext{
${ }^{6}$ This paragraph relies primarily on Slayton (1966) and Groberg (1968). Also see Foard and Fefferman (1960) and Sogg and Wertheimer (1959). We proceed as if the supply of grants was elastic for projects that met program requirements. In fact, funding was subject to Congressional authorization and therefore to year-to-year changes in funding constraints.

${ }^{7}$ Approximately 54 percent of the displaced families were nonwhite (HUD 1966). For perspective, the 1950 Census of Housing characterized approximately 1.3 million units in metropolitan areas as “dilapidated” (defined in notes to Table 1).
} 
1965, Abrams 1966, Slayton 1966), political support for the program eroded. New funding halted in 1974.

\section{B. Potential Effects: Urban Renewal and Spatial Equilibrium}

Once a local urban renewal program was undertaken, how might it have affected city-level outcomes? The most direct impact would be on the areas targeted for clearance, redevelopment, or rehabilitation. By knocking down relatively low-quality housing and commercial buildings, the left-hand tail of the distribution of building quality might be thinned out, and the means and medians of various city-level measures might rise mechanically. However, the implicit model held by proponents of urban renewal emphasized the role of substantial spillovers within the city. ${ }^{8}$ Blight was considered geographically contagious, detrimental to the well-being of people living in or near such areas, a growing drain on public resources, and both a cause and consequence of middle-class flight and local governments' fiscal problems. It was argued that reversing the fortunes of specific areas would benefit the city through a virtuous circle (e.g., less blight, less outmigration, and higher property values across the city), or at least by shortcircuiting the process of deterioration. In this context, recourse to eminent domain was important because assembling sizable areas of urban land through individual negotiations with multiple property owners is costly and subject to holdouts (Davis and Whinston 1961). In addition to effects emanating from specific projects, the program's emphasis on code enforcement, city-wide planning, and neighborhood rehabilitation might have had broader impacts (Guandolo 1956, Carey 2001).

Urban renewal attempted to make central-city locations more attractive to both businesses and residents. In an inter-city spatial equilibrium model with freely mobile workers, capital, and goods, as described by Roback (1980, 1982), a higher level of local amenities that are valued by both workers and firms ("productive amenities") tends to raise equilibrium property values because for any given wage level, both workers and firms are willing to pay more to locate in that place. The amenities have an ambiguous effect on wages, however, because for any given rent level, workers are willing to accept lower wages to have access to the amenity, but firms are

\footnotetext{
${ }^{8}$ Ioannides (2002) and Rossi-Hansberg, Sarte and Owens (2010) find evidence of spillovers in housing markets. Brueckner and Helsley (2011) model market failures that lead to urban blight and suburban sprawl.
} 
willing to pay higher wages. Figure 1 illustrates the simplest version of the model. $\mathrm{V}\left(w, r ; \alpha_{1}\right)$ is an indirect utility curve showing how consumers are willing to trade off wages $(w)$ for rent $(r)$, given a level of local amenities, $\alpha_{1}$. $\mathrm{C}\left(w, r ; \alpha_{1}\right)$ shows the isocost tradeoff for competitive firms. A change in productive amenities from $\alpha_{1}$ to $\alpha_{2}$ leads to a shift of both curves, a rise in $r$, and the theoretically ambiguous movement of $w$. We return to this framework when discussing the empirical results in Section IV. ${ }^{9}$

A complementary intra-city view is developed by Hornbeck and Keniston (2011), which describes how cities rebuilt after large fires in the nineteenth century. Their framework highlights how the interaction of local externalities, plot consolidation, private investment, and new public infrastructure can lead to long-term increases in land and building values after a major fire. The essence is that in each period property owners optimally choose between keeping an old building (and receiving rent associated with that quality of building) and constructing a new building at higher quality on the same site. Fires exogenously remove the option of keeping the old building and may mitigate coordination problems, leading to higher post-fire values for buildings and land. ${ }^{10}$ In this framework, one might think of slum clearance and urban renewal as the policy equivalent of large fires. We return to this idea in Section IV, as well.

Of course, it cannot be taken for granted that urban renewal had any noticeable impact on cities’ level of amenities, productivity, or prices. Schall (1976), for example, develops an intracity model that features externalities in property upkeep and shows that renewal-like efforts to raise local housing quality may be unsustainable. When the pre-program equilibrium is at a relatively low level of quality, targeted improvements have short-lived effects; however, the possibility of multiple equilibria in the model allows for a sustained, positive urban renewal effect. Whether the urban renewal program actually had economically significant effects on American cities remains an open empirical question.

\footnotetext{
${ }^{9}$ Although the simple model delivers key insights, several extensions of this framework are worth noting. First, in the presence of agglomeration economies, there may be multiplier effects as population and productivity changes positively reinforce one another. Second, allowing workers to have different tastes for specific locations relaxes the perfect mobility assumption. Third, housing supply adjustment plays an important role in accommodating population change and determining the relative magnitude of changes in factor prices. See Glaeser and Gottlieb (2009) and Moretti (2011) for further discussion.

${ }^{10}$ In our data we observe city-level residential property values, but not separate values for land and buildings, let alone separate values inside and outside urban renewal areas. Therefore, we cannot disentangle the model's distinctions between land and building value changes.
} 


\section{Empirical Strategy}

\section{A. Data and Empirical Framework}

The goals of Title I were broad and predicated on the belief that targeted improvements within a city could have positive effects for the city as a whole. Because the goals and hypothesized effects were city-wide in scope and because the program was carried out by city governments, we examine the link between urban renewal activity and city-level outcomes reported in the federal censuses of population and housing. ${ }^{11}$ We collected information on urban renewal activity from HUD's Urban Renewal Directory, last published in 1974. For each city, the Directory lists the value of federal grants approved and disbursed up to the publication date. This includes both urban renewal projects and funds for smaller initiatives that were added under the urban renewal programs umbrella. The close connection between federal funding and urban renewal expenditure ensures that variation across cities in federal urban renewal grants is a good indicator of variation in urban renewal activity, particularly after controlling for pre-existing differences in city characteristics. ${ }^{12}$

We scale the "grants approved" figure by the population of each city in 1950 and call this variable $U R_{i j}$, where $i$ represents the city and $j$ the census division (there are nine census divisions in the U.S., each consisting of a contiguous group of states). All regressions will control for census-division indicators and city-specific characteristics that might confound the interpretation of differences in grant levels across cities, such as pre-existing differences in property values. ${ }^{13}$ The instrumental-variable strategy, discussed below, addresses concerns

${ }^{11}$ City-specific case studies, such as White (1980) would complement this paper's analysis, but such analysis would entail a difficult selection problem at the neighborhood level. Unfortunately, the data underlying White (1980) could not be recovered (personal communication with author). Our search at the National Archives and inquiries to HUD did not uncover a systematic collection of city-specific plans.

${ }^{12}$ Data from HUD (1966) indicate that the city-level correlation between urban renewal project grants and urban renewal gross project costs is 0.99 at that point in time. Independently, our full measure of urban renewal grants per capita (based on HUD 1974b) is strongly correlated with the percentage of city acres cleared (based on HUD 1966). The correlation coefficient is 0.39 with a p-value less than 0.0001 .

${ }^{13}$ HUD's Urban Renewal Directory (1974b) reports total nominal sums approved and dispersed as of June 30, 1974 for each city. It is not feasible to precisely adjust each city's nominal sum for inflation over the course of the program, but we have undertaken an analysis in this spirit. For each city, we assumed that projects were undertaken at a constant rate from the year of the city's first project execution until 1974, and we used the GDP deflator series to scale the nominal sums. Effectively, urban renewal spending in early years gets scaled up in value relative to later years. The IV regression results with this 
regarding the endogeneity of funding and measurement error in the true intensity of urban renewal activity.

The central empirical question examined in this paper is whether more intensive urban renewal programs $\left(U R_{i j}\right)$ led to better economic outcomes in $1980\left(Y_{i j}\right)$ conditional on the 1950 value of $Y_{i j}$, several other city-level characteristics at the time of the federal program's implementation, and indicator variables for the nine census divisions $\left(\boldsymbol{\delta}_{j}\right)$. In other words, did cities that were observationally similar in 1950 experience different growth paths depending on the intensity of urban renewal activity? If so, then we would expect estimates of $\beta_{1}$ in equation (1) to be positive.

$$
Y_{i j 80}=\alpha+\beta_{1} U R_{i j}+\mathbf{X}_{i j 50}^{\prime} \boldsymbol{\beta}_{2}+\boldsymbol{\delta}_{j}+u_{i j 80}
$$

Note that the list of control variables, $\mathbf{X}_{i j 50}$, in equation (1) always includes the 1950 value of the outcome variable. ${ }^{14}$ We do not control for changes in $\mathbf{X}_{i j}$ between 1950 and 1980 because such changes are likely to be endogenous. Indeed, changes in several city-level housing, population and, economic characteristics are investigated as potential program effects. The main outcome variables of interest are the log of median value of owner occupied property, log of median family income, employment rate, and poverty rate. Subsequent analyses examine additional outcomes, including population and housing stock variables.

The extensive set of pre-program control variables $\left(\mathbf{X}_{i j 50}\right)$ includes: housing stock characteristics in 1950 (the percentage of housing units built before 1920, the percentage that were dilapidated, the percentage that lacked indoor plumbing, the percentage that were crowded, the percentage that were owner-occupied, and the log median value of owner-occupied units);

adjusted UR variable are similar to those reported below, but the coefficients are somewhat lower. An alternative re-scaling of the grants adjusts for cross-place differences in price levels. We divided the city's grants by the ratio of the city's median property value in 1950 over the sample's average median property value in 1950. This scales down the "real" value of grants in places with high pre-program property values. Again, the results are similar which is not surprising because the $\mathbf{X}$ variables and fixed effects control for cross-place differences in characteristics. We prefer the simple approach that takes the reported values from the Urban Renewal Directory at face value.

${ }^{14}$ See Angrist and Pischke (2009, 243-247) for discussion of specifications that control for the preprogram value of the dependent variable, as in our base specification. We believe this is an appropriate choice because one might expect participation in the urban renewal program to be influenced by the preprogram level of $Y$. For comparison with the base results reported in Table 3, regressions with $\Delta Y_{i j 1980-1950}$ as the dependent variable (and excluding the lagged dependent variable from the list of controls) are reported in Appendix Table A4. 
population characteristics in 1950 (the nonwhite percentage of the population, median educational attainment of those over age 24 , and the log of the city's total population); and economic characteristics in 1950 (log median family income, the employment rate, the percentage of employment in manufacturing, and the percentage of families with income below $\$ 2,000$ [a proxy for poverty]). The census-division indicator variables capture differences in trends across regions. Summary statistics and data sources are provided in the Appendix.

The main econometric problem in interpreting an estimate of $\beta_{1}$ as a program effect is that urban renewal projects were initiated, planned, and carried out at the local level. Even with a rich set of city-level, pre-program control variables $\left(\mathbf{X}_{i j 50}\right)$ and census-division indicators $\left(\boldsymbol{\delta}_{j}\right)$, unobservable city-level shocks might be correlated with both the intensity of program participation and subsequent economic outcomes. Cities that were deteriorating relative to others in ways that are not captured by the control variables might have pursued a large volume of urban renewal projects; such cities might have ended up with worse economic outcomes than other cities in 1980 but with better outcomes than if they had gone without the program (the OLS coefficient on funding would understate the true impact of UR funding). Or, the opposite case could hold—cities with profitable investment opportunities might have enthusiastically pursued urban renewal projects. Such places might have posted relatively strong outcomes in 1980 even if the renewal program had no real effect. We address this problem by finding plausibly exogenous variation in city-level urban renewal funding that is due to differences in the timing of state-enacted enabling legislation.

\section{B. Discussion of Enabling Legislation}

State enabling legislation permitted and set legal parameters for the creation of local public agencies (LPAs) that could exercise eminent domain to acquire property for private redevelopment, a key element of the urban renewal process. This legislation was crucial to the implementation of federally funded urban renewal projects and is often cited in the early social science literature that considers cross-city differences in funding (e.g., Straits 1965, Plott 1968, and Bingham 1975), in historical accounts of urban renewal initiatives (e.g., Teaford 1990, Fairbanks 2002 and 2006, Germany 2007), in considerations of the program's legal aspects (e.g., Sogg and Wertheimer 1959, Pritchett 2003), and in urban planning publications (e.g., see Greer and Hansen 1941 and issues of the National Association of Housing and Redevelopment 
Officials' Journal of Housing). Archival material indicates that HHFA (HUD's predecessor) closely monitored the development of enabling legislation because it determined cities' ability to participate in the program. ${ }^{15}$

Given that enabling legislation was a prerequisite to federally funded urban renewal, that political opposition to the program increased with time, that there was learning-by-doing in formulating project proposals, and that new funding halted in 1974, a delay in enabling legislation would narrow a city's window of opportunity for urban renewal efforts. There is historical evidence that state legislative delays constrained the participation of cities that wanted to undertake urban renewal. ${ }^{16}$ A priori, such constraints might seem most likely to bind for smaller cities with comparatively little political influence, but even large cities were sometimes affected by delays in enabling legislation. This interpretation is emphasized in studies by historian Robert Fairbanks, who notes that "When Congress passed the Housing Act of 1949, Dallas and Phoenix civic leaders applauded the new law as an important aid in their fight against bad housing and downtown blight" (2006, 309). However, he reports that, "The delay in stateenabling legislation deeply inhibited Dallas's ability to participate in slum clearance and redevelopment during the 1950s and 1960s" (2006, 310) and that "Despite the initial burst of enthusiasm, Phoenix, like Dallas, had to wait until state legislators passed the necessary enabling legislation” (2006, 315). In other work, Fairbanks argues that "No urban redevelopment would be allowed in Texas until the state passed enabling legislation specifically permitting cities to establish redevelopment authorities. The delay would have dire consequences for many Texas cities since it halted implementation of the program in the state and allowed opponents of urban renewal to organize an effective lobby” $(2002,186)$.

\footnotetext{
${ }^{15}$ For example, a memo from C.L. Farris (Chief of Field Operations) to H.S. Keith (Director of Slum Clearance and Urban Redevelopment) dated December 5, 1950 discusses cities that are interested in Title I funds pending the passage of appropriate state enabling legislation. A memo from A. Foard (Assistant General Counsel) to Charles Horan (Area 4 Supervisor) dated May 10, 1951 describes the status of enabling legislation in the West (National Archives, College Park, Maryland, Record Group 207, Urban Renewal Administration, General Subject Files).

${ }^{16}$ In states that did not pass enabling legislation quickly, the Journal of Housing reports on repeated efforts, spearheaded by cities, to introduce and pass the legislation. Separately, several cities are listed in the Congressional Quarterly Almanac (Congressional Quarterly 1949, 286) as "Communities for S 1070 and HR 4009" (the Housing Act of 1949) that are in states that passed enabling legislation relatively late, implying that they were constrained in their program participation. Bingham $(1975,84)$ reports that later enabling legislation tended to be more restrictive in terms of requirements for referenda on urban renewal programs and projects.
} 
It is difficult to generalize from existing sources about the determinants of variation in the timing of enabling legislation. In our sample of cities, the standard $\mathbf{X}_{i j 50}$ variables are not strong predictors of the timing of enabling legislation. ${ }^{17}$ In this sense, the timing looks fairly idiosyncratic from the cities' perspective, which is important to the identification strategy. Nonetheless, three broad themes emerged in our reading about delays in enabling legislation, and these motivate some of the robustness checks undertaken later in the paper.

First, some early opponents saw the program as an undue extension of federal influence on local affairs and an encroachment on individual property rights. This point of view gained traction in the context of cold-war, anti-socialist sentiment and may have forestalled or limited the scope of enabling legislation. Second, within state legislatures, representatives from rural areas sometimes opposed policies perceived to be biased in favor of urban development. ${ }^{18}$ Both themes suggest that the politics that influenced urban renewal legislation could plausibly spill over to other policies that differentially affected cities. Later in the paper, however, we show that the main empirical results are unaffected by adding controls for state-level conservatism, state-level policies toward cities, and programs such as public housing that expanded at the same time as urban renewal. A third consideration is grounded in judicial concerns rather than legislative ones. In Georgia, South Carolina, and Florida, rulings by state courts delayed the implementation of urban renewal programs due to relatively narrow interpretations of the "public use" qualification for eminent domain. Whereas courts in other states interpreted "public use" fairly broadly and specifically allowed for private redevelopment under Title I, courts in these

\footnotetext{
${ }^{17}$ In city-level regressions of years-of-potential-participation in urban renewal (based on timing of enabling legislation) on $\mathbf{X}$ and census division fixed effects, none of the coefficients on $\mathbf{X}$ is significant at the 5 percent level, and only log population size and percentage of housing that is dilapidated are significant at the 10 percent level. These are always included as controls in the regression analyses.

${ }^{18}$ These themes are prominent in the history of Louisiana's long road to enabling legislation (Forman 1969, Germany 2007). Forman (1969, 262) quotes a state representative from Grosse Tête, Louisiana, in 1967 (attributed to an article by Thorn in The Shreveport Times, June 17): "[Governor McKeithen] got into trouble for promises he had made to support urban renewal. Then, when the country boys put on the pressure and got him to see the political liability of urban renewal in the coming election, he escaped by keeping the session fiscal and thereby killing urban renewal—at least for the present.” In Texas, Fairbanks (2006) notes that although representatives from Dallas, Fort Worth, and San Antonio pushed for the state-enabling legislation, representatives from rural areas and various industry groups (e.g., Texas Real Estate Board and Texas Association of Home Builders) worked to defeat it. In state-level regressions, however, we find no strong statistical evidence that the urban proportion of the state population affected the timing of enabling legislation (available upon request).
} 
three states were less accommodating. Later in the paper, we test whether an IV estimate based solely on these judicial delays confirms the basic results.

If delays of enabling legislation (1) affected city-level urban renewal participation, (2) did not influence city-level outcomes through other channels, and (3) are not correlated with unobserved factors that did influence outcomes, then the timing of enabling laws may serve as a credible instrumental variable for urban renewal funding. In the paper's next subsection, we focus on examining the first condition-whether enabling legislation affected city-level funding levels. The specific nature of the urban renewal enabling legislation makes it unlikely to have influenced outcomes through any channel other than urban renewal program participation (condition 2). Potential omitted variables and unobservables (condition 3), such as contemporaneous social and urban programs, secular economic trends, differences in political conservatism, and relevant state policies are assessed in Section III.

Appendix Table A2 reports the year of enabling legislation for each state. ${ }^{19}$ One practical shortcoming of the enabling legislation variable is that cross-city variation within the industrial Northeast and Midwest is very limited. Most states in these areas adopted enabling legislation within a year or two of the federal Housing Act of 1949. Nonetheless, there is sufficient variation in the full sample to see whether differences in eligibility for urban renewal translated into differences in city-level outcomes. We return to this issue later in the paper when discussing the results in Section III.

\section{Urban Renewal Activity and Enabling Legislation}

Table 1 reports ordinary-least-squares regression estimates of equation (2), where $U R_{i j}$ is urban renewal grants per capita (in city $i$ and census division $j$ ) and $L_{i j}$ is each city's “years of potential participation” in the federal urban renewal program, defined as the difference between 1974 and the year in which enabling legislation was passed.

\footnotetext{
${ }^{19}$ In our main analysis, we generally use the year of state enabling legislation that is implicit in Aiken and Alford (1998). Because Aiken and Alford's data are, in effect, topcoded in 1966, we assign later dates for some cities in Louisiana and South Carolina. See the notes to Appendix Table A2 for more details. We also report results using an alternative coding of state enabling legislation based on the earliest or latest date of enabling legislation in the state (Table 3, rows 6 and 7). An earlier version of this paper used the Aiken and Alford coding “as is” (e.g., without adjustment for topcoding), and results were consistent with those reported in this version.
} 


$$
U R_{i j}=\gamma+\tau_{1} L_{i j}+\mathbf{X}^{\prime}{ }_{i j 50} \boldsymbol{\tau}_{2}+\lambda_{j}+e_{i j}
$$

Similar to equation (1), $\mathbf{X}_{i j 50}$ is an extensive set of city-level characteristics in 1950 , and $\boldsymbol{\lambda}_{j}$ is a set of census-division fixed effects (again, there are nine census divisions). For consistency with the IV regressions that follow, we use a sample of 458 cities with populations of at least 25,000 in 1950 and 1980 and without missing data on outcome or control variables. ${ }^{20}$ Hawaii, Alaska, and Washington, DC are omitted. If enabling legislation constrained cities' ability to plan, apply for, and receive federal grants, then estimates of $\tau_{1}$ should be positive.

Table 1's first regression specification (column 1) includes only the census-division fixed effects and $L_{i j .}{ }^{21}$ Heteroskedasticity-robust standard errors are adjusted for correlation within states. The results indicate that an additional year of eligibility for participation is associated with 9.71 additional dollars of grants per capita; the standard error is 2.67 . In column 2, the estimate of $\tau_{1}$ is virtually unaffected by adding the full set of 13 control variables for observable city characteristics $\left(\mathbf{X}_{i j 50}\right)$ that one might expect to underpin local demand for urban renewal projects. Rather than being undercut, the estimate of $\tau_{1}$ increases slightly (from 9.71 to 10.32 ) and remains statistically significant. This pattern is consistent with state enabling legislation affecting local urban renewal funding in a manner that is essentially independent of local characteristics.

The specification in column 2 corresponds to the first-stage of the baseline IV estimates that are presented in the paper's next section, where we address concerns about the instrument's excludability from the second-stage at length. We have tested the robustness of the first-stage relationship extensively. Additional control variables for local political conservatism, city tax revenue per capita in 1950, state income per capita, and new federal highway mileage have little influence on the estimate of $\tau_{1}{ }^{22}$ The correlation between funding and enabling legislation also remains strong when omitting cities with over 500,000 residents or the largest city in each state, or when dropping each census division from the sample in turn. Thus, the first-stage correlation

\footnotetext{
${ }^{20}$ The population threshold reflects the availability of city-level census data in Haines (2004).

${ }^{21}$ Tobit regressions also suggest strong and statistically significant correlations. We focus on OLS results for consistency with the first-stage regressions of the IV estimates that follow.

${ }^{22}$ Conservatism is proxied by the proportion of county votes for Barry Goldwater in 1964's presidential election. Goldwater opposed urban renewal programs, and 1964 was the first year the Republican Party's platform criticized urban renewal, so this is a relevant gauge of local conservatism. Nate Baum-Snow kindly supplied highway data from his paper on suburbanization (2007). We lose almost half of the sample when controlling for the change in central-city federal highway miles, but estimates of $\tau_{1}$ are similar with and without the highway control variable in that small sample.
} 
reported in Table 1, column 2, is not driven by otherwise unobserved differences in political orientation, willingness or ability to tax, cross-state income differences, the sample's largest cities, or an idiosyncratic census division.

In summary, legal requirements, historical studies, and archival information indicate that the timing of state enabling legislation constrained cities' ability to participate in the urban renewal program. Delays in access to the program narrowed the window of opportunity for planning and carrying out urban renewal projects. This interpretation is supported statistically by a strong link between the quantity of local urban renewal funding and the year of state enabling legislation, even when controlling for observable city characteristics. The regression results are consistent with a pattern of quasi-random assignment of enabling legislation across cities within census divisions.

\section{Urban Renewal Effects}

\section{A. Reduced-Form Results and a Falsification Test with Rural Counties}

If state enabling legislation substantially affected cities’ ability to participate in the urban renewal program and if benefits from participation actually existed, then one would expect to find evidence that city-level economic outcomes are correlated with variation in enabling legislation $\left(L_{i j}\right)$ in reduced-form regressions (Angrist and Krueger 2001). However, if state enabling legislation for urban renewal strongly predicts outcomes in rural areas, that would suggest that the paper's main instrumental variable is correlated with unobserved determinants of post-1950 economic outcomes, and therefore an invalid basis for making causal inferences about the program's effects (assuming that positive spillovers from urban renewal are not strongly felt in rural areas).

The first row of Table 2 reports reduced-form regressions for cities, controlling for the same set of pre-program characteristics ( $\mathbf{X}_{i j 50}$ which includes the 1950 value of the dependent variable) and census-division indicators as described above. ${ }^{23}$ There is strong evidence of a positive correlation between economic outcomes and years of potential participation in the urban renewal program. For instance, 5 extra years of enabling legislation is associated with 3.6 percent higher

\footnotetext{
${ }^{23}$ For comparison, Appendix Table A3 reports results with $\Delta Y_{i j 1980-1950}$ as the dependent variable, rather than using the lagged dependent variable as a control. See footnote 14 for related discussion.
} 
median property values and 1.2 percent higher family income. An added-variable plot of the data underlying the property value result is shown in Figure 2, panel A.

We constructed a separate dataset of rural counties using Haines (2004), defining counties as “rural” if they had less than 25 percent urban population in 1950. This yields approximately 1,500 counties in 46 states, or about half of all U.S. counties. Because some states passed enabling legislation in stages (discussed below), row 2 assigns each rural county the earliest year of its state's enabling legislation, whereas row 3 assigns the latest year of the state's extension of enabling legislation. In both cases, the regression results show no evidence of a relationship between urban renewal enabling legislation and outcomes in the rural counties. ${ }^{24}$ Coefficients in the rural county regressions never approach statistical significance, and they are often small and have the opposite sign relative to the city-level results. This strongly suggests that the instrumental variable is not simply reflecting unobserved differences across states in economic trends. Figure 2, panel B, is an added-variable plot of the property value and enabling legislation data for rural countries.

\section{B. Instrumental Variable Regression Results}

We estimate the effect of urban renewal activity in equation (1) by instrumenting for funding $\left(U R_{i j}\right)$ with the amount of time eligible for participation under enabling legislation $\left(L_{i j}\right)$. In all the regressions we include the full set of city-level control variables $\left(\mathbf{X}_{i j 50}\right)$, as well as the censusdivision dummy variables. The implicit first-stage regression results are the same as those in Table 1, column 2. The F-statistic for the instrumental variable in the first-stage regression is 13.8, a fairly strong relationship that should mitigate biases associated with weak instruments and with deviations from the assumed exclusion restriction (Bound, Jaeger, and Baker 1995; Staiger and Stock 1997; Stock, Wright, and Yogo 2002; Conley, Hansen, and Rossi 2012).

The base-specification estimates of $\beta_{1}$ are reported in row 1 of Table 3 , where each table entry is from a separate regression. The results suggest that urban renewal programs led to higher median income and higher median property values at a 5 percent level of statistical significance. The estimated effects on the employment rate and percentage of families in poverty are less precisely estimated, but they are consistent with favorable effects.

\footnotetext{
${ }^{24}$ The county-level control variables are similar to those in our city-level regressions, but not exactly the same due to the availability of variables in Haines (2004). See Table 2 notes.
} 
For a program that is widely held in low regard, the basic results in Table 3 are striking: a \$100 per capita difference in grant funding is associated with a 2.4 percent difference in 1980 median income and a 6.9 percent difference in 1980 median property value. The median city in our dataset received \$122 per capita in funding, and so the coefficient estimates imply an economically significant impact. Because total investment in local urban renewal (the combination of private and public resources) was an unknown multiple of the federal grants that we observe, and because these resources might have been invested elsewhere in the absence of urban renewal programs (e.g., more suburban development), the coefficients from these citylevel regressions must be interpreted with care. They are not estimates of the social returns on investment or local fiscal multipliers. William Slayton, who was Commissioner of the Urban Renewal Administration in HHFA, suggests that the ratio of private investment to federal grants for urban renewal projects was over \$5-to-\$1 (1966, 221). Because it is difficult to verify this number or the scope of private investment it entails, we hesitate to give it too much weight, but taken at face value, it implies that urban renewal entailed large investments in central cities beyond the nominal value of federal grants. $^{25}$

For perspective on the magnitude of the estimated urban renewal effects, we can turn to a more recent analysis of differential changes in property values in response to an exogenous infusion of investment. In a well-identified study, Greenstone and Moretti (2004, 26) conclude that making the winning bid for a large new manufacturing plant in the 1980s and 1990s raised county-level property values by 6.6 to 10.2 percent relative to other counties over a six-year period. Our citylevel property value results are roughly the same order of magnitude for a median amount of urban renewal grants per capita, though of course we are looking at central cities, where the effects might be concentrated relative to counties, and over a longer period of time. ${ }^{26}$

\footnotetext{
${ }^{25}$ The relatively large infusion of private investment in concert with urban renewal initiatives is also emphasized by proponents of urban renewal in Williams et al. (1973).

${ }^{26}$ Another comparison is provided by a recent revitalization effort in Richmond, Virginia. RossiHansberg, Sarte, and Owens (2010) found that the ratio of land-value appreciation to program spending was about 5-to-1. It is difficult to make direct comparisons with our framework due to differences in definitions of program spending and land versus property value changes. A back-of-envelope calculation with our data suggests that a 6.9 percent increase in 1980 median property value implies a property value appreciation/program spending ratio of about 3-to-1. This calculation entails scaling \$100 of nominal UR grants per capita to approximately $\$ 900$ in 1980 dollars per household, adjusting for inflation and assuming four persons per household.
} 
It is interesting that the IV regression results are substantially more positive than comparable OLS results, which are reported in Appendix Table A5. ${ }^{27}$ Assuming for now that the instrument is valid, this suggests that urban renewal funding was correlated with unobserved negative shocks or trends, which bias downward the OLS estimates of urban renewal effects.

\section{Robustness to Additional Controls}

We consider several scenarios in which the basic estimates of urban renewal effects might be confounded by omitted variables. Essentially, these are circumstances under which the instrument is hypothetically correlated with the error term in equation (1), violating "condition 3" described above. Later, we test the sensitivity of the results to a substantial recoding of the enabling legislation instrumental variable and to using an instrumental variable that is based on state court rulings that delayed program participation.

First, it is possible that programs that were coincident with urban renewal influenced city-level outcomes. If cities' decisions to participate in these programs were uncorrelated with the timing of state-enabling legislation for urban renewal, then the IV estimates would still be valid. But since some programs were related to urban renewal (e.g., established in related legislation or motivated by similar concerns), we have run regressions that include control variables for the number of public housing units per capita built under Housing Act of 1949; whether the city filed a first-round application for the Johnson Administration’s “Model Cities” program; and citylevel spending per capita on poverty programs circa 1966. If the IV regression results were simply picking up a positive influence from these other programs, then the additional control variables should diminish the coefficient on urban renewal funding. Instead, the results in row 2 of Table 3 show that including the "other program” variables in the regressions tends to increase the magnitude of the coefficient on the urban renewal variable.

Second, high-quality local governments might be more adept at applying for project grants, getting the necessary enabling legislation passed, and carrying out other functions that affect city-level outcomes. This interpretation seems inconsistent with the results in row 2, where participation in public housing and Model Cities may proxy for local government initiative or administrative capability. It also seems inconsistent with the OLS results, where one might

\footnotetext{
${ }^{27}$ The null hypothesis of exogenous urban renewal funding is rejected at the 5 percent level in the regressions for income, property value, and employment rate.
} 
expect to see a positive link between outcomes and urban renewal funding if good local governments were coincidentally good grant writers and effective lobbyists. We have undertaken additional investigation of the government-quality hypothesis by collecting Moody's city bond ratings for 1950 (Porter 1950). The ratings should reflect forward-looking views of cities' fiscal soundness, which in turn depend on the quality of local management and underlying economic prospects. Not all cities had ratings available, and so we assigned cities to one of three categories for analysis: relatively high ratings (Aaa to A ratings), relatively low ratings (Baa and below), and "rating not available." The results are similar to those in row $1 .^{28}$ We have uncovered no evidence that the quality or characteristics of local government drive the results.

Third, it is possible that differences in the timing of state enabling legislation are correlated with cross-state differences in support for cities. If differences in such support contributed to differences in city-level outcomes in 1980, then the estimates above would exaggerate the effects of urban renewal. Therefore, we collected information on state aid directed to city governments in 1952 from a Bureau of Census publication (U.S. Department of Commerce 1954b). Expressed relative to the urban population's size in each state, this provides a state-level variable that controls for differences in state government policy with respect to cities. We also included a control variable for cross-state differences in political conservatism: the state-level percentage of votes for Barry Goldwater in the 1964 presidential election. ${ }^{29}$ Row 3 of Table 3 reports the IV coefficients on urban renewal funding from regressions that include both of these state-level control variables. Again, the overall results are similar to those in row 1 , with somewhat larger coefficients and standard errors. ${ }^{30}$ Results are also similar if analogous variables for state-aid to cities in 1962 or 1972 are added.

Fourth, secular shifts in the US economy may have favored some places relative to others. If these differential trends are correlated with differences in the timing of enabling legislation

${ }^{28}$ The coefficients and standard errors are as follows, where the subscript denotes the regression's dependent variable: $\beta_{\text {value }}=0.000693$ (0.000332); $\beta_{\text {inc }}=0.000241(0.000110) ; \beta_{\text {emp }}=0.003395(0.00199)$; $\beta_{\text {pov }}=-0.00612(0.005095)$. Adding controls for bond ratings in 1982 do not alter the results, nor does controlling for the type of local government (e.g., mayor-council, city manager, nonpartisan elections).

${ }^{29}$ Results are similar if we include a control variable based on a comprehensive index calculated by Ranney (1965) that reflects differences in support for Democrats during the 1946 to 1963 period, when most enabling legislation was passed.

${ }^{30}$ An archival HHFA document from 1962 listed five states known to provide some direct financial support for urban renewal: Connecticut, Illinois, Massachusetts, New York, and Pennsylvania. Adding a dummy variable for this group of states had little effect on the estimates of interest. 
within census division, the estimated urban renewal effects would be invalid. The city-level control variables for economic and population characteristics, including the percentage of employment in manufacturing, should narrow the scope of this problem. We can further address the issue by including a control variable that interacts detailed (three-digit) state-level industrial composition in 1950 with national-level industry-specific growth rates between 1950 and 1980 (Bartik 1991), which we constructed using information from the Integrated Public Use Microdata Series (IPUMS, Ruggles et al. 2008). ${ }^{31}$ The census division controls should capture much of the secular rise of the "sunbelt," but we have also included a control variable for mean January temperature which others have found to be a strong predictor of city growth in this period (Glaeser and Tobio 2008). The results are reported in row 4 of Table 3 and are similar to the base results in row 1.

Finally, we dropped the largest city in each state from the sample. This leaves us with a sample of cities within each state that are less politically influential and more likely to find the timing of enabling legislation exogenous to their circumstances and demands. The results are reported in row 5 . They are similar to the base results, and in most cases are marginally stronger in magnitude and statistical significance. Dropping all cities with more than 500,000 residents in 1950 also yields results that are similar to the baseline estimates. The base results are also robust to dropping cities in states that were relative outliers in terms of adopting enabling legislation. ${ }^{32}$

The robustness checks do not suggest that the basic results are driven by omitted variables that are correlated with the instrument and influence the outcomes of interest directly. Although it is not possible to completely rule out contamination from unobservable shocks that are correlated with the instrument, such shocks would have to operate differentially across cities within census divisions in a manner that is not captured by the extensive set of base-specification control variables and subsequent robustness checks, and that conforms to the falsification test with rural counties.

\footnotetext{
${ }^{31}$ The 1950 census microdata are not sufficiently detailed to construct this variable at the city level.

${ }^{32}$ Cities in Idaho, Wyoming, Utah, South Carolina, and Louisiana faced the longest delays in enabling legislation. Omitting cities with less than 10 years of enabling legislation (14 cities according to the base coding of Aiken and Alford) does not undermine key results. The point estimate on property value rises while the point estimate on income falls; both remain economically and statistically significant.
} 


\section{Robustness to Changing Instruments}

We start by replacing the original instrumental variable based on the timing of enabling legislation with two alternative codings. Although we have confidence in the original variable's coding in Aiken and Alford (1998), the underlying sources for their coding are not well documented. Therefore, we independently reconstructed the timeline of enabling laws from a wide variety of sources (see notes to Appendix Table A2). Reassuringly, our coding turned out to be similar to that in Aiken and Alford (1998), albeit not exactly the same. A separate concern is that a handful of states passed legislation for a specific city before allowing broader participation. This introduces some within-state variation in the instrument that may be a function of city-specific demand. We created two alternative codings that are based on our reading of the legislative history and make adjustments so that all cities in each state are assigned the same "years of exposure" value.

Row 6 of Table 3 reports results when all cities in each state are assigned the earliest date of state enabling legislation, and row 7 reports results when all cities in each state are assigned the latest date. Due to differences in our base coding relative to Aiken and Alford and to the shifting of assignments in some states to either the earliest or latest date of state legislation, about 20 percent of cities have a different "years of exposure" value in rows 6 and 7 than in previous rows. Nonetheless, the pattern of regression results is similar to that in previous rows.

We have also run the regressions replacing the original instrument with an indicator variable that equals one if the state supreme court invalidated enabling legislation due to a relatively narrow interpretation of what constitutes a valid use of eminent domain. This happened in South Carolina, Georgia, and Florida. With this instrument, variation in predicted funding that enters the second stage is driven by differences in judicial interpretations that delayed program participation and created uncertainty about the scope and nature of legally viable projects. The results are reported in row 8 . The first-stage relationship between the indicator and funding is strongly negative (F-statistic $=32.2$ ), and the second-stage results are generally similar to those in row 1 . When we restrict the sample to southern cities, we get results that are consistent with those in row 8, but with somewhat larger point estimates and standard errors. ${ }^{33}$

\footnotetext{
${ }^{33}$ The coefficients and standard errors are as follows: $\beta_{\text {value }}=0.00125(0.000499) ; \beta_{\text {inc }}=0.000370$ (0.000251); $\beta_{\mathrm{emp}}=0.00696(0.00375) ; \beta_{\mathrm{pov}}=-0.00734(0.00684)$. There are 117 southern cities in the
} 
Using both years-of-potential-participation and state court reversals as instruments in the twostage-least-squares regressions yields estimates that are close to the base results. ${ }^{34}$ Both instruments are strongly correlated with funding in the first-stage regression. With more than one instrumental variable, an overidentification test can assess whether the instruments are correlated with the regression errors, which would raise concerns about instrument validity. In each regression, the overidentification test cannot reject the null hypothesis that the instruments are valid. ${ }^{35}$ In combination with the other robustness checks, this lends additional confidence regarding the credibility of the empirical strategy.

\section{E. Qualifications and Additional Results}

Two important qualifications attach to the basic results. First, as mentioned earlier, variation in the enabling legislation instrument is relatively large outside the Northeast and Midwest regions, and the precision of the base results depends in part on this variation. In reduced-form regressions with the sample restricted to cities in the Northeast and Midwest, the point estimates on years-of-eligibility-for-urban-renewal remain positive and roughly similar in magnitude to those from the full sample estimates (some increase and some decline in magnitude), but the standard errors are larger. ${ }^{36}$

Second, examination of county-level data suggests that the effects of urban renewal were concentrated within central cities. In a sample of counties that were located in Standard Metropolitan Areas (as defined in 1950) and in an overlapping but different sample of counties that contain the cities of our city-level dataset, reduced-form regressions of economic outcomes on the enabling-legislation instrument and standard control variables yield results that are relatively weak in magnitude and statistical significance (reported in Appendix Table A6). From

regressions. Standard errors cannot be clustered by state in this case but are similar if clustered by metropolitan area or county codes.

${ }^{34}$ The coefficients and standard errors are: $\beta_{\text {value }}=0.000758(0.000306) ; \beta_{\text {inc }}=0.000246(0.000088)$; $\beta_{\text {emp }}=0.00449$ (0.00215); and $\beta_{\text {pov }}=-0.00675$ (0.004385).

${ }^{35}$ The p-value on the Hansen J-statistic (overidentification test) is: 0.68 in the property-value regression; 0.93 in the income regression; 0.38 in the employment regression; and 0.77 in the poverty regression.

${ }^{36}$ When restricted to cities in the Northeast and Midwest, the reduced-form coefficients and (standard errors) are $0.00703(0.00462)$ for property value, 0.00409 (0.00278) for income, $0.0571(0.0667)$ for employment, $-0.0684(0.136)$ for poverty, and $0.00631(0.00433)$ for population. See Table 2, row 1 for comparison with the full sample results. 
this perspective, the gains observed at the city-level did not carry over to the county-level, suggesting a limited scope for positive geographic spillovers. Indeed, it is possible that economic activity was pulled to central cities at the expense of surrounding areas, leading to small or negligible net gains at the county level.

We have also attempted to glean more information on the patterns of urban renewal effects at the city-level by examining outcome data from 1960 and 1970. The nature of urban renewal makes it difficult to closely tie the timing of projects to the timing of changes in local outcomes. Cities often undertook multiple projects starting at different times, and the typical project took more than 10 years to complete. Because urban renewal programs within cities span census dates between 1950 and 1980, our main analyses have focused on pre- and post-program outcomes. Nonetheless, reduced-form regressions with pooled outcome data from the 1960, 1970, and 1980 censuses reveal interesting patterns.

In equation (3), city-level outcomes observed in 1960, 1970, and $1980\left(Y_{i j t}\right)$ are regressed on years of eligibility for urban renewal as of year $t\left(L_{i j t}\right)$; the standard set of control variables, $\mathbf{X}_{i j 50 \text {, }}$ which as always includes the 1950 value of $Y$; and census-division-by-year fixed effects $\left(\boldsymbol{\sigma}_{j t}\right)$.

$$
Y_{i j t}=\theta_{t}+\pi_{1 t} L_{i j t}+\mathbf{X}_{i j 50}^{\prime} \boldsymbol{\pi}_{2 t}+\boldsymbol{\sigma}_{j t}+v_{i j t}
$$

Coefficient values are allowed to change in each census year, so this is similar to running separate cross-section regressions for each census year. The $\pi_{1 t}$ coefficients reveal how responsive outcomes were to differences in eligibility for urban renewal as of each census date. The regression results are reported in Table 4. There is strong evidence of a link between urban renewal eligibility and property value by the 1970 census, but no evidence that urban renewal had affected median property values in 1960. This suggests a gradual adjustment in self-reported residential property values as the program unfolded. For income and employment, on the other hand, there is strong evidence of a connection as early as 1960, about 10 years after the first states started implementing urban renewal. This is consistent with the program providing a stimulus to local economic activity, which was one of the goals of the legislation. However, we note in our discussion below that the effect on income is still apparent in year 2000 data, indicating that the relative gains were not temporary in nature. 


\section{Channels of Influence}

If the urban renewal program affected city-level economic outcomes, as the regression results suggest, how were these results achieved? One can imagine urban renewal's effect working through a narrow, mechanical, and perhaps even perverse channel-essentially knocking down the left-hand tail of the housing-quality distribution and driving people with low levels of human capital and earnings out of the city. We will refer to this as the "displacement channel," which works by altering the composition of the city's population. Of course, a mechanism that merely displaces the poor from the city is quite different from the mechanism touted by proponents of urban renewal and from that of the Rosen-Roback model with enhanced local productivity. Urban renewal proponents argued that the program could impart a virtuous circle of renewal and growth or at least dampen an ongoing circle of deterioration. We will refer to this as the "renewal and growth channel." These two channels are not mutually exclusive. Displacement of the poor, for example, could occur as a byproduct of rising property values, which are driven by gains in local amenities or productivity.

We shed light on these issues in two ways. First, in IV regressions that are similar to those above (described in equation (1)), we directly examine whether urban renewal affected city-level proxies for the "displacement” or "renewal and growth" channels. Then, to see if the basic results in Table 3 are driven by changes in population characteristics, as the displacement hypothesis would suggest, we add control variables for potentially endogenous population characteristics (observed in 1980) to the base regressions from Table 3. If the displacement channel were the primary means by which the program affected outcomes, we would expect to see smaller coefficients on urban renewal.

The first two columns of Table 5 estimate the effect of urban renewal on the median schooling level of the adult population and the black percentage of the population. If urban renewal worked by disproportionately displacing from the city those with low levels of human capital or minority residents, then one would expect the urban renewal coefficient in the schooling regression to be strongly positive or the coefficient in the black-share-of-population regression to be strongly negative. We find no support for these hypotheses. The estimated effect on schooling is small and imprecise, and there is no reduction in the black population (the point 
estimate is positive), even though black residents were disproportionately displaced from renewal areas within cities. $^{37}$

The next four columns of Table 5 assess aspects of the "renewal and growth" channel. The middle two columns report estimates of the effect on the overall size of the population and housing stock in 1980, controlling for their size in 1950, changes in land area, and the base set of 1950 control variables (X, including the 1950 value of the dependent variable). The estimates suggest that the urban renewal program positively affected city population and housing units; a $\$ 100$ per capita increase in urban renewal funding is associated with a 9 to 11 percent increase in population and housing units in the base specifications. The point estimates are notably smaller, however, when only the court reversal instrument is used (row 8).

In the last two columns, urban renewal is associated with a lower proportion of old housing units in 1980 (i.e., units built before 1940). The coefficient suggests that an additional \$100 per capita in funding decreased the share of old housing by 3 percentage points. The estimated effect on units-without-full-plumbing is also negative, but it is relatively imprecise. ${ }^{38}$ The sizable effects on the age of the housing stock, the size of the housing stock and population, and other city-level outcomes (in Table 3) suggest substantial local spillovers from the urban renewal program beyond the narrow confines of each project location.

In Table 6, we re-run the base regressions from Table 3 and add control variables that proxy for displacement: the racial and educational composition of the city in 1980. The additional control variables may be endogenous to urban renewal, and so the resulting coefficients on urban renewal funding are no longer interpreted as estimates of the program's overall effect. Rather, the point is to see whether changes in city population characteristics underpin the coefficients estimated in Table 3's baseline regressions. The first row of Table 6 simply replicates the original results from Table 3 for easier comparison; the table's second row adds controls for the percentage black in 1980 and median schooling in 1980. The coefficients on urban renewal are slightly larger in the augmented regressions, and so it seems highly unlikely that the positive estimated effects of urban renewal in Table 3 are driven by changes in the city's basic population characteristics.

\footnotetext{
${ }^{37}$ In a similar regression for the proportion of adults (age 25 and up) with less than four years of high school completion (rather than median schooling), we also get a small, imprecise point estimate.

${ }^{38}$ The census did not classify housing units as “dilapidated" in 1980, but in 1950 the correlation between the percent of units dilapidated and the percent of units without full plumbing was 0.77 .
} 
The weight of evidence in Tables 5 and 6 is not consistent with a simple story in which urban renewal perversely raised city-wide outcome variables through displacement of those with relatively low levels of human capital. The results are, however, consistent with a "renewal and growth” mechanism. In particular, the combination of higher wages, property values, and populations is consistent with higher local productivity in the Rosen-Roback model, as depicted by the rightward shift of $\mathrm{C}(r, w ; \alpha)$ in Figure $1 .^{39}$

The results are also broadly consistent with the framework described by Hornbeck and Keniston (2011), where property values may rise in the wake of events that mitigate inherent coordination problems in urban settings and that facilitate major new public and private investments. Under urban renewal, cities should have been able to target areas where the benefits from solving these problems were large. Although, we cannot examine the detailed predictions of the Hornbeck and Keniston model with our city-level data, the mechanisms they cite - new and higher quality buildings on consolidated plots of land with expanded and improved infrastructure-are reminiscent of urban renewal proposals.

The productivity-based interpretation is also consistent with the fact that the estimated urban renewal effects do not dissipate with time. In year 2000 city-level data, IV estimates of $\beta_{1}$ are larger than those found in 1980, though the standard errors are also larger. ${ }^{40}$ If the program had only provided a short-run stimulus to cities by spurring building activity and infusing federal grants through the 1970s, then we would expect the coefficients to fade by 2000.

In some settings, property value changes may be interpreted as changes in local welfare. For instance, in studying local efforts to attract new manufacturing plants, Greenstone and Moretti (2004) describe a Roback-model framework in which property values fully capitalize the local costs and benefits of attracting a plant. They are careful, however, to qualify this interpretation given the model's strong assumptions (e.g., costless mobility and identical workers) and the

${ }^{39}$ Glaeser and Gottlieb (2009) suggest that productivity and amenity parameters may be backed out of a Cobb-Douglas representation of the Roback model using regressions of wage, housing cost, and population change. There is considerable distance between measurement and theory in this exercise, but taken at face value, calculations suggest that urban renewal positively affected tradable sector productivity, had little effect on consumer amenities, and negatively affected non-tradable productivity.

${ }^{40}$ The base specification estimates with 2000 outcome data are: $\beta_{\text {value }}=0.00116(0.000525) ; \beta_{\text {inc }}=$ $0.000645(0.000231) ; \beta_{\mathrm{emp}}=0.00715(0.00271) ; \beta_{\mathrm{pov}}=-0.0107(0.006575)$. The larger point estimates in 2000 might reflect the operation of agglomeration economies, in which a positive initial effect on local productivity reinforces itself with time. Given the large standard errors, we hesitate to make strong inferences based on the relative magnitude of the point estimates for 2000 compared to those for 1980 . 
distance between theory and measurement (e.g., land versus property values). We are especially cautious in drawing inferences about changes in welfare in the context of urban renewal given the literature's emphasis on the disproportionate costs borne by those displaced by the program, which would not be capitalized in local property values. Thinking beyond local effects, it is clear that something that is good for a particular city might not be good for other areas if economic activity has merely been relocated or if tax revenues are drawn from some places to benefit others.

\section{Conclusion}

The early post-war decades, especially the 1960s and 1970s, were far from an optimistic time in most American central cities, as residents and economic activity drained away (see Cullen and Levitt 1999, Baum-Snow 2007, and Boustan 2010). To some critics, the urban renewal program was a prima facie failure because it did not prevent or reverse urban economic decline. The spreading perception of failure-punctuated by riots, rising crime rates, and municipal fiscal crises - combined with concerns about the costs borne by the displaced and slow pace of redevelopment eventually led to the program’s political demise. In a 50-year anniversary retrospective on the 1949 Housing Act, Robert Lang and Rebecca Sohmer wrote, “The consensus is that Title I urban renewal mostly failed, in part because large-scale slum clearance proved a crude and largely unworkable redevelopment method” (2000, 296). In the same volume, Jon Teaford highlighted the usefulness of lessons learned from urban renewal and examples of well-regarded projects, but he also noted “...the chief product of Title I was a widely held commitment never to have another Title I” (2000, 463). Nonetheless, the fundamental policy issues and tools associated with urban renewal remain highly relevant, and there is much to be learned from the U.S. experience with government-facilitated urban redevelopment. The large literature on urban renewal is highly critical but remarkably thin when it comes to providing econometric evidence on the program's effects.

This paper's results strongly suggest that, on average, cities that were less constrained in their urban renewal participation had larger increases in property values, income, and population than similar cities that were more constrained in their participation. This implies a far less dismal legacy than is commonly portrayed. The patterns are consistent with the program spurring more central-city growth than otherwise would have occurred, rather than simply demolishing the left- 
hand tail of the housing quality distribution and pushing low-earning residents out of the city. We find no evidence that the positive estimates of urban renewal effects are underpinned by changes in the observable characteristics of cities' residents. Again, it is important to acknowledge that the city-level results do not imply that the costs imposed on relatively poor residents and small businesses that were displaced by urban renewal were unimportant, nor do they imply that the program was an optimal approach to assisting cities, let alone the best possible use of federal resources.

The results are broadly consistent with studies that find that targeted local investments may have sizable economic impacts due to the strength of local externalities and spillovers (cf., Greenstone and Moretti 2004, Greenstone, Hornbeck, and Moretti 2010, Rossi-Hansberg, Sarte, and Owens 2010). Evidence of urban renewal program effects in city-level outcomes suggests the presence of spillovers beyond the narrow confines of each project area since the projects themselves usually constituted a relatively small portion of each city. Arguments along these lines are common in legal and political settings to justify policy interventions and the use of eminent domain, but causal evidence supporting such claims is still relatively scarce. Examining similar policies in other settings, undertaking further explorations of the causal pathways, and measuring the distributional consequences of such policies are important avenues for further research. 


\section{Appendix: Data Sources, Summary Statistics, and Additional Results Housing and Population Data Sources}

We manually entered data for the percent of dilapidated housing units, units built before 1920, units without full plumbing, and crowded units for 1950 from the published volumes of the census of housing in 1950 (U.S. Department of Commerce 1954a). Data for dilapidated units and units without full plumbing are from Table 18, data for crowded units are from Table 19, and data for units built before 1920 are from Table 20. We collected data on the percent of families with incomes less than \$2,000 from Table 11 in the published volumes of the Characteristics of Population in the 1950 Population Census (U.S. Department of Commerce 1953). We collected data on median years of schooling of adults (over age 24) in 1980 from Table 119 of the General Social and Economic Characteristics volume of the 1980 Census of Population.

The data for population, land area, housing units, percent employment, median family income, median property values, percent of owner occupied housing, and percent of employment for 1950 and 1980 are from the 1952 and 1983 City Data Book files compiled by Haines (2004, file numbers 60 and 66). These files also provide data for the percent of nonwhite residents, percent employment in manufacturing, and median schooling in 1950, and for the percent black, percent of crowded units, occupied units without full plumbing, families in poverty, and old units in 1980. The 1983 City Data Book provides mean January temperatures, averaged from 1951 to 1980.

City-level data for 2000 was retrieved from the U.S. Census's American Fact Finder website (U.S. Department of Commerce 2012, factfinder2.census.gov/). From here, we collected data on population (Table ID P001), median income (Table ID P077), median property values (Table ID H076), the poverty rate (Table ID P099), and the employment rate (Table ID P043).

County-level data for population, area, median property values, median family income, and percent employment for 1950 and 1980 are from the 1952 and 1983 County Data Book files compiled by Haines (2004, file numbers 72 and 78). These files also provided county-level data for the percent of owner-occupied housing, the percent of units with running water that are not dilapidated, the percent of units built after 1940, median rooms per unit, persons per occupied unit, the percent of nonwhite residents, the percent of employment in manufacturing, median 
schooling, the percent of families with less than \$2,000 income, and an indicator for whether counties were located in SMAs in 1950, and the percent of families in poverty in 1980.

\section{Election, Government Spending, and Enabling Legislation Data Sources}

Votes for Goldwater in the 1964 Presidential Election were entered from David Leip's Atlas of U.S. Presidential Elections. Data for state aid to cities were entered from "State Payments to Local Governments in 1952" in State and Local Government Special Studies, 35, published by the U.S. Department of Commerce (1954b). These data were divided by state urban population from the 1950 Characteristics of the Population ("old definition” of urban, U.S. Department of Commerce 1953).

Urban Renewal state enabling legislation data are derived from Governmental Units Analysis Data (GUAD, Aiken and Alford 1998). Please see the notes and sources to Appendix Table A2 for more details on the enabling legislation dates, including our independent coding as an alternative to Aiken and Alford's. Data for units of public housing per capita built under the 1949 Housing Act, spending per capita on poverty programs circa 1966, and applications to the Model Cities program are also from $G U A D$. We collected Urban Renewal funding data from the Urban Renewal Directory (U.S. Department of Housing and Urban Development 1974b). 
Appendix Table A1: Summary Statistics

\begin{tabular}{|c|c|c|}
\hline Variable & Mean & $\begin{array}{l}\text { Standard } \\
\text { deviation }\end{array}$ \\
\hline UR funds per capita (1950 population) & 177.043 & 221.444 \\
\hline $\begin{array}{l}\text { Years of potential participation in UR } \\
\text { program }\end{array}$ & 22.504 & 4.483 \\
\hline Ln population 1980 & 11.297 & 0.886 \\
\hline Ln median family income 1980 & 9.827 & 0.171 \\
\hline Employment rate 1980 & 92.632 & 2.925 \\
\hline Percent of families in poverty 1980 & 11.040 & 5.143 \\
\hline Median years of schooling 1980 & 12.467 & 0.717 \\
\hline Percent black 1980 & 16.136 & 17.817 \\
\hline Ln housing units 1980 & 10.385 & 0.895 \\
\hline Ln median property value 1980 & 10.627 & 0.363 \\
\hline Percent of units built before 1940 & 37.232 & 18.788 \\
\hline Percent of units w/o full plumbing 1980 & 1.665 & 0.907 \\
\hline Ln population 1950 & 11.090 & 0.879 \\
\hline Ln median family income 1950 & 8.120 & 0.175 \\
\hline Employment rate 1950 & 94.950 & 2.018 \\
\hline \multicolumn{3}{|l|}{ Percent of families with income under } \\
\hline$\$ 2000$ in 1950 & 21.410 & 8.997 \\
\hline Median years of schooling 1950 & 10.310 & 1.268 \\
\hline Percent nonwhite 1950 & 9.282 & 11.816 \\
\hline Ln housing units 1950 & 9.901 & 0.885 \\
\hline Ln median property value 1950 & 9.027 & 0.293 \\
\hline Percent of 1950 units built before 1920 & 49.414 & 21.784 \\
\hline Percent of units dilapidated & 6.623 & 5.578 \\
\hline Percent of units crowded 1950 & 12.727 & 6.587 \\
\hline Percent of units w/o full plumbing 1950 & 21.723 & 13.412 \\
\hline Percent of units owner-occupied 1950 & 52.317 & 11.690 \\
\hline \multicolumn{3}{|l|}{ Percent of employment in manufacturing } \\
\hline 1950 & 29.508 & 15.247 \\
\hline New England & 0.120 & \\
\hline Mid Atlantic & 0.157 & \\
\hline East North Central & 0.245 & \\
\hline West North Central & 0.083 & \\
\hline South Atlantic & 0.116 & \\
\hline East South Central & 0.055 & \\
\hline West South Central & 0.085 & \\
\hline Mountain & 0.039 & \\
\hline Pacific & 0.100 & \\
\hline
\end{tabular}

Notes and sources: See Table 1 and data sources described above. 
Appendix Table A2: State Enabling Legislation

\begin{tabular}{|c|c|c|c|}
\hline & $\begin{array}{c}\text { Aiken and } \\
\text { Alford coding }\end{array}$ & $\begin{array}{c}\text { Alternative } \\
\text { coding, } \\
\text { earliest year }\end{array}$ & $\begin{array}{c}\text { Alternative } \\
\text { coding, } \\
\text { latest year }\end{array}$ \\
\hline \multicolumn{4}{|l|}{ South } \\
\hline \multicolumn{4}{|c|}{ South Atlantic Division } \\
\hline Delaware & 1951 & 1951 & 1951 \\
\hline Florida & 1959 & 1957 & 1969 \\
\hline Georgia & 1955 & 1954 & 1954 \\
\hline Maryland & 1949/1959 & 1949 & 1959 \\
\hline North Carolina & 1951 & 1951 & 1951 \\
\hline South Carolina & 1958/1969* & 1966 & 1971 \\
\hline Virginia & 1949/1956 & 1949 & 1949 \\
\hline West Virginia & 1951 & 1951 & 1951 \\
\hline \multicolumn{4}{|l|}{ East South Central } \\
\hline \multicolumn{4}{|l|}{ Division } \\
\hline Alabama & 1949 & 1949 & 1949 \\
\hline Kentucky & 1949 & 1950 & 1950 \\
\hline Mississippi & 1958 & 1958 & 1958 \\
\hline Tennessee & 1949 & 1949 & 1949 \\
\hline \multicolumn{4}{|l|}{ West South Central } \\
\hline \multicolumn{4}{|l|}{ Division } \\
\hline Arkansas & 1949* & 1949 & 1949 \\
\hline Louisiana & $1955 / 1974 *$ & 1968 & 1974 \\
\hline Oklahoma & 1959 & 1959 & 1959 \\
\hline Texas & 1957 & 1957 & 1957 \\
\hline \multicolumn{4}{|c|}{ Northeast } \\
\hline \multicolumn{4}{|c|}{ New England Division } \\
\hline Connecticut & 1949 & 1949 & 1949 \\
\hline Maine & $1951 / 1959$ & 1951 & 1959 \\
\hline Massachusetts & 1949 & 1949 & 1949 \\
\hline New Hampshire & 1949 & 1949 & 1949 \\
\hline Rhode Island & 1950 & 1950 & 1950 \\
\hline Vermont & 1957 & 1957 & 1957 \\
\hline \multicolumn{4}{|l|}{ Middle Atlantic } \\
\hline \multicolumn{4}{|l|}{ Division } \\
\hline New Jersey & 1949 & 1949 & 1949 \\
\hline New York & 1949 & 1950 & 1950 \\
\hline Pennsylvania & 1949 & 1949 & 1949 \\
\hline $\begin{array}{l}\text { Midwest } \\
\text { East North Centra } \\
\text { Division }\end{array}$ & & & \\
\hline
\end{tabular}




\begin{tabular}{lccc} 
Indiana & 1949 & 1949 & 1953 \\
Illinois & 1949 & 1949 & 1949 \\
Michigan & 1949 & 1949 & 1949 \\
Ohio & $1949 *$ & 1949 & 1949 \\
Wisconsin & 1949 & 1949 & 1949 \\
& & & \\
West North Central & & & \\
Division & 1957 & 1957 & 1957 \\
Iowa & 1955 & 1951 & 1957 \\
Kansas & 1949 & 1949 & 1949 \\
Minnesota & $1949 / 1951$ & 1949 & 1951 \\
Missouri & 1951 & 1951 & 1957 \\
Nebraska & 1955 & 1955 & 1955 \\
North Dakota & 1950 & 1950 & 1950 \\
South Dakota & & & \\
Mountain Division & 1954 & 1954 & 1954 \\
Arizona & 1949 & 1949 & 1949 \\
Colorado & 1965 & 1965 & 1959 \\
Idaho & 1959 & 1959 & 1959 \\
Montana & 1959 & 1959 & 1957 \\
New Mexico & 1957 & 1957 & 1965 \\
Nevada & 1965 & 1965 & 1965 \\
Utah & 1965 & 1959 \\
Wyoming & & & 1957 \\
Pacific Division & 1949 & 1959 & \\
California & 1957 & & \\
Oregon & & & \\
Washington & & & \\
\hline
\end{tabular}

Notes and sources: Column 1 is based on information in Aiken and Alford (1998, henceforth AA). AA provides variables for "years after 1949 that it took the city to enter the urban renewal program" and "years between the first year that state enabling legislation would permit city to be in the urban renewal program and the year the city first entered the urban renewal program." The year of enabling legislation can be backed out of those two variables. Because sometimes one city would be granted enabling legislation before other cities in the same state, the AA coding has some within-state variation (albeit rarely). In such cases, the first column reports the "earliest/latest" year for cities in our dataset. We generally use the AA coding "as is" in the paper and check the results (Table 3) against those obtained when using our own "earliest" and "latest" coding, which is reported above in columns 2 and 3 . However, the asterisks $\left(^{*}\right)$ in column 1 indicate states where we made adjustments to the implicit AA coding. The AA dates are essentially topcoded in 1966. For example, AA codes New Orleans as 1955 and other cities in Louisiana as 1966 (topcode), but in Louisiana enabling legislation permitting private redevelopment, a cornerstone of the urban renewal program, was first passed in 1968. New Orleans undertook a few public-use projects before 1968, hence AA's early date. See Journal of Housing (1968), Forman (1969), and Germany (2007) on Louisiana's enabling legislation. We left the AA coding for New Orleans as 1955, but changed other cities to 1968 (if covered in the legislation of that year) or 1974 (if not covered, implying zero years of eligibility). AA topcodes Greenville, SC as 1966. We reset this value to 1969 based on the date of a constitutional amendment allowing Greenville’s full participation in urban renewal. John Wallis (personal 
correspondence) kindly provided information on South Carolina's constitution. AA's coding for other cities in South Carolina (Columbia, Charleston, and Spartanburg) reflects early public-use projects and predates the first amendment allowing private use. As in New Orleans, we leave these dates in place in the AA coding scheme, but in our independent coding (columns 2 and 3) we focus on the dates of amendments permitting private redevelopment in South Carolina counties. Two cities had dates of 1945 in the AA data (Canton, Ohio and Little Rock, Arkansas), and we have reset these values to 1949, the start of the urban renewal program. Earlier versions of this paper did not make any of these adjustments to the AA data and obtained similar results. Columns 2 and 3 are based on our independent collection of information on the earliest and latest dates of state enabling legislation from the Book of the States (Council of State Governments, various years), the Journal of Housing (various years), U.S. Housing and Home Finance Agency (1958 and 1962), Forman (1969), Fairbanks (2006), Johnson and Tashman (2002), and Graham (2007), where we sought direct confirmation of the original AA coding. In South Carolina, amendments allowing urban renewal with private redevelopment for some places were passed as late as 1973, but those later amendments were not binding on cities in our dataset. 
Appendix Table A3: Comparison of City and Rural-County Outcomes,

Reduced-form Regressions of Outcomes on Instrumental Variable, $\Delta \mathrm{Y}_{1980-1950}$ is the Dependent Variable

\begin{tabular}{|c|c|c|c|c|c|}
\hline & $\begin{array}{l}\text { Ln median } \\
\text { property } \\
\text { value } \\
\end{array}$ & $\begin{array}{l}\text { Ln median } \\
\text { family } \\
\text { income } \\
\end{array}$ & $\begin{array}{l}\text { Employment } \\
\text { rate }\end{array}$ & Poverty rate & $\begin{array}{c}\text { Ln } \\
\text { population }\end{array}$ \\
\hline $\begin{array}{l}\text { 1. Sample of cities, } \\
\text { IV based on year of } \\
\text { enabling legislation }\end{array}$ & $\begin{array}{c}0.00762 \\
(0.00362)\end{array}$ & $\begin{array}{c}0.00226 \\
(0.00104)\end{array}$ & $\begin{array}{c}0.0295 \\
(0.0290)\end{array}$ & $\begin{array}{l}-0.0327 \\
(0.0673)\end{array}$ & $\begin{array}{c}0.00808 \\
(0.00562)\end{array}$ \\
\hline $\begin{array}{l}\text { 2. Sample of rural } \\
\text { counties, } \\
\text { IV based on earliest year } \\
\text { of state enabling } \\
\text { legislation }\end{array}$ & $\begin{array}{c}0.00191 \\
(0.00420)\end{array}$ & $\begin{array}{c}-0.000991 \\
(0.00157)\end{array}$ & $\begin{array}{l}0.00568 \\
(0.0503)\end{array}$ & $\begin{array}{c}-0.0146 \\
(0.0610)\end{array}$ & $\begin{array}{c}-0.00250 \\
(0.00477)\end{array}$ \\
\hline $\begin{array}{l}\text { 3. Sample of rural } \\
\text { counties, } \\
\text { IV based on latest year of } \\
\text { state enabling legislation }\end{array}$ & $\begin{array}{c}-0.00263 \\
(0.00316)\end{array}$ & $\begin{array}{c}-0.000154 \\
(0.00136)\end{array}$ & $\begin{array}{c}-0.00681 \\
(0.0304)\end{array}$ & $\begin{array}{c}0.0264 \\
(0.0487)\end{array}$ & $\begin{array}{c}-0.00473 \\
(0.00400)\end{array}$ \\
\hline
\end{tabular}

Notes: Regressions in this table use $\Delta Y$ as the dependent variable, rather than our base specification with a lagged dependent variable (see Table 2 for direct comparison). Each coefficient is from a separate OLS regression of an economic outcome on years of eligibility for urban renewal (based on the timing of state enabling legislation) and control variables. Row 1's sample includes the cities examined in Table 1. Rows 2 and 3 include rural counties (less than or equal to 25 percent urban population in 1950, approximately half of all U.S. counties). The underlying control variables for the city and county regressions are very similar but not exactly the same due to data availability in Haines (2004). Differences are as follows: whereas the city regressions control for proportion of housing units built before 1920 (and counted in 1950), the county regressions control for the proportion of units built between 1940 and 1950 (and counted in 1950); whereas the city regressions control separately for the proportion of units without full plumbing and the proportion of units dilapidated, the county regressions control for the proportion with full plumbing and not dilapidated (a single variable); and whereas the city regressions control for the proportion of units with more than 1 person per room, the county regressions control for median number of rooms per unit and median number of persons per unit. Standard errors are clustered by state.

Sources: See data sources described above. 
Appendix Table A4: Urban Renewal Effects on Property Value, Income, Employment, and Poverty, $\Delta \mathrm{Y}_{1980-1950}$ is the Dependent Variable

\begin{tabular}{|c|c|c|c|c|}
\hline & $\begin{array}{l}\text { Ln median } \\
\text { property value }\end{array}$ & $\begin{array}{c}\text { Ln median } \\
\text { family income }\end{array}$ & $\begin{array}{l}\text { Employment } \\
\text { rate }\end{array}$ & Poverty rate \\
\hline $\begin{array}{l}\text { Panel A: Basic specification } \\
\text { 1: Controls for } 1950 \\
\text { characteristics, census division }\end{array}$ & $\begin{array}{c}0.000720 \\
(0.000336)\end{array}$ & $\begin{array}{c}0.000219 \\
(0.000102)\end{array}$ & $\begin{array}{c}0.00289 \\
(0.00270)\end{array}$ & $\begin{array}{l}-0.00316 \\
(0.00620)\end{array}$ \\
\hline $\begin{array}{l}\text { Panel B: Additional controls } \\
\text { 2: Add controls for public } \\
\text { housing, poverty spending, } \\
\text { Model Cities }\end{array}$ & $\begin{array}{c}0.00103 \\
(0.000503)\end{array}$ & $\begin{array}{c}0.000395 \\
(0.000202)\end{array}$ & $\begin{array}{c}0.00526 \\
(0.00354)\end{array}$ & $\begin{array}{l}-0.00824 \\
(0.00931)\end{array}$ \\
\hline $\begin{array}{l}\text { 3: Add controls for state aid to } \\
\text { cities and support for Goldwater }\end{array}$ & $\begin{array}{c}0.00102 \\
(0.000379)\end{array}$ & $\begin{array}{c}0.000268 \\
(0.000131)\end{array}$ & $\begin{array}{c}0.00591 \\
(0.00373)\end{array}$ & $\begin{array}{l}-0.00744 \\
(0.00675)\end{array}$ \\
\hline $\begin{array}{l}\text { 4: Add controls for labor-demand } \\
\text { shift (based on industrial } \\
\text { composition) and mean January } \\
\text { temperature }\end{array}$ & $\begin{array}{c}0.000729 \\
(0.000335)\end{array}$ & $\begin{array}{c}0.000248 \\
(0.000108)\end{array}$ & $\begin{array}{c}0.00335 \\
(0.00269)\end{array}$ & $\begin{array}{l}-0.00504 \\
(0.00624)\end{array}$ \\
\hline 5: Drop largest city in each state & $\begin{array}{c}0.000625 \\
(0.000319)\end{array}$ & $\begin{array}{c}0.000230 \\
(0.0000911)\end{array}$ & $\begin{array}{c}0.00306 \\
(0.00251)\end{array}$ & $\begin{array}{l}-0.00326 \\
(0.00570)\end{array}$ \\
\hline $\begin{array}{l}\text { Panel C: Changing instruments } \\
\text { 6: Alternative legal coding, } \\
\text { earliest year of enabling leg. }\end{array}$ & $\begin{array}{c}0.000845 \\
(0.000423)\end{array}$ & $\begin{array}{c}0.000277 \\
(0.000121)\end{array}$ & $\begin{array}{c}0.00508 \\
(0.00315)\end{array}$ & $\begin{array}{l}-0.00787 \\
(0.00722)\end{array}$ \\
\hline $\begin{array}{l}\text { 7: Alternative legal coding, latest } \\
\text { year of enabling leg. }\end{array}$ & $\begin{array}{c}0.000744 \\
(0.000387)\end{array}$ & $\begin{array}{c}0.000272 \\
(0.000104)\end{array}$ & $\begin{array}{c}0.00421 \\
(0.00300)\end{array}$ & $\begin{array}{l}-0.00385 \\
(0.00594)\end{array}$ \\
\hline $\begin{array}{l}\text { 8: State supreme court reversal of } \\
\text { enabling legislation }\end{array}$ & $\begin{array}{c}0.000908 \\
(0.000376)\end{array}$ & $\begin{array}{c}0.000178 \\
(0.0000933)\end{array}$ & $\begin{array}{c}0.00827 \\
(0.00395)\end{array}$ & $\begin{array}{l}-0.00331 \\
(0.00520)\end{array}$ \\
\hline
\end{tabular}

Notes: Regressions in this table use $\Delta Y$ as the dependent variable, rather than our base specification with a lagged dependent variable (see Table 3 for direct comparison). The top entry of each cell is the estimated coefficient on urban renewal funding per capita from a separate instrumental variable regression. Heteroskedasticity-robust standard errors are adjusted for correlation within states and reported in parentheses below the coefficient. See Table 1's notes for variable definitions.

Sources: See data sources described above. 
Appendix Table A5: OLS Results for Comparison with IV Results (in Tables 3 and 5)

\begin{tabular}{|c|c|c|c|}
\hline \multirow[b]{2}{*}{ Ln median value } & \multicolumn{2}{|c|}{ Panel A } & \multirow[b]{2}{*}{ Poverty rate } \\
\hline & $\begin{array}{l}\text { Ln median family } \\
\text { income }\end{array}$ & Employment rate & \\
\hline $\begin{array}{l}-.0000747 \\
(.0000467)\end{array}$ & $\begin{array}{c}-.0000371 \\
(.0000213)\end{array}$ & $\begin{array}{l}-.00140 \\
(.000613)\end{array}$ & $\begin{array}{c}.000512 \\
(.000883)\end{array}$ \\
\hline \multicolumn{4}{|c|}{ Panel B } \\
\hline Ln population & Median schooling & Percent black & \\
\hline $\begin{array}{l}.00000860 \\
(.0000504)\end{array}$ & $\begin{array}{l}.000109 \\
(.0000807)\end{array}$ & $\begin{array}{c}.00386 \\
(.00250)\end{array}$ & \\
\hline \multicolumn{4}{|c|}{ Panel C } \\
\hline Ln housing units & $\begin{array}{l}\text { Percent old housing } \\
\text { units }\end{array}$ & $\begin{array}{l}\text { Percent w/o full } \\
\text { plumbing }\end{array}$ & \\
\hline $\begin{array}{l}.0000323 \\
(.0000479)\end{array}$ & $\begin{array}{l}-.00534 \\
(.00234)\end{array}$ & $\begin{array}{l}-.000394 \\
(.000191)\end{array}$ & \\
\hline
\end{tabular}

Notes and sources: See Table 3, Table 5, and data sources described above. 
Appendix Table A6: City and County-Level Reduced-Form Results, including Metro Area Counties or Counties Containing Cities in the City-Sample

\begin{tabular}{|c|c|c|c|c|c|}
\hline & $\begin{array}{c}\text { Ln median } \\
\text { property } \\
\text { value } \\
\end{array}$ & $\begin{array}{l}\text { Ln median } \\
\text { family } \\
\text { income } \\
\end{array}$ & $\begin{array}{l}\text { Employment } \\
\text { rate }\end{array}$ & Poverty rate & Ln population \\
\hline $\begin{array}{l}\text { 1. Sample of cities, } \\
\text { IV based on year of } \\
\text { enabling legislation }\end{array}$ & $\begin{array}{c}0.00715 \\
(0.00368)\end{array}$ & $\begin{array}{c}0.00249 \\
(0.00114)\end{array}$ & $\begin{array}{c}0.0347 \\
(0.0213)\end{array}$ & $\begin{array}{l}-0.0630 \\
(0.0547)\end{array}$ & $\begin{array}{c}0.00936 \\
(0.00551)\end{array}$ \\
\hline $\begin{array}{l}\text { 2. Sample of } 1950 \\
\text { metro counties, } \\
\text { IV based on earliest } \\
\text { year of state } \\
\text { enabling legislation }\end{array}$ & $\begin{array}{c}0.00449 \\
(0.00354)\end{array}$ & $\begin{array}{l}0.000250 \\
(0.00157)\end{array}$ & $\begin{array}{l}-0.00371 \\
(0.0353)\end{array}$ & $\begin{array}{c}0.0392 \\
(0.0597)\end{array}$ & $\begin{array}{c}0.00263 \\
(0.00485)\end{array}$ \\
\hline $\begin{array}{l}\text { 3. Sample of } 1950 \\
\text { metro counties, } \\
\text { IV based on latest } \\
\text { year of state } \\
\text { enabling legislation }\end{array}$ & $\begin{array}{c}0.00345 \\
(0.00265)\end{array}$ & $\begin{array}{l}0.000917 \\
(0.00128)\end{array}$ & $\begin{array}{l}0.00113 \\
(0.0256)\end{array}$ & $\begin{array}{c}0.0134 \\
(0.0416)\end{array}$ & $\begin{array}{l}-0.00136 \\
(0.00401)\end{array}$ \\
\hline $\begin{array}{l}\text { 4. Sample of } \\
\text { counties containing } \\
\text { cities of city- } \\
\text { sample, } \\
\text { IV based on earliest } \\
\text { year of state } \\
\text { enabling legislation }\end{array}$ & $\begin{array}{c}0.00213 \\
(0.00315)\end{array}$ & $\begin{array}{c}0.00189 \\
(0.00114)\end{array}$ & $\begin{array}{r}-0.00124 \\
(0.0212)\end{array}$ & $\begin{array}{l}-0.0737 \\
(0.0485)\end{array}$ & $\begin{array}{r}-0.000209 \\
(0.00409)\end{array}$ \\
\hline $\begin{array}{l}\text { 5. Sample of } \\
\text { counties containing } \\
\text { cities of city- } \\
\text { sample, } \\
\text { IV based on latest } \\
\text { year of state } \\
\text { enabling legislation }\end{array}$ & $\begin{array}{c}0.00234 \\
(0.00261)\end{array}$ & $\begin{array}{c}0.00243 \\
(0.000913)\end{array}$ & $\begin{array}{c}0.000247 \\
(0.0161)\end{array}$ & $\begin{array}{l}-0.0524 \\
(0.0307)\end{array}$ & $\begin{array}{l}-0.00219 \\
(0.00288)\end{array}$ \\
\hline
\end{tabular}

Notes: Each coefficient is from a separate OLS regression of an economic outcome on years of eligibility for urban renewal (based on the timing of state enabling legislation) and control variables. Row 1's sample includes the cities examined in Table 1. Rows 2 and 3 include counties that were in Standard Metro Areas as defined in 1950. Rows 4 and 5 include counties that contain the cities from the city sample (whether or not they were in metro areas). The underlying control variables for the city and county regressions are very similar but not exactly the same due to data availability in Haines (2004). See Table 2 notes for details on differences. Standard errors are clustered by state.

Sources: See data sources described above. 


\section{REFERENCES}

Abrams, Charles. 1966. “Some Blessings of Urban Renewal” In Urban Renewal: The Record and the Controversy, edited by James Q. Wilson, 64-76. Cambridge, MA: MIT Press.

Aiken, Michael and Robert Alford. 1998. “Governmental Units Analysis Data.” Inter-university Consortium for Political and Social Research (ICPSR), ed. Ann Arbor, MI: ICPSR [producer and distributor]. doi:10.3886/ICPSR00028.v1 (accessed: May 27, 2008).

Anderson, Martin. 1964. The Federal Bulldozer: A Critical Analysis of Urban Renewal, 19491962. Cambridge, MA: MIT Press.

Angrist, Joshua D., and Jorn-Steffen Pischke. 2009. Most Harmless Econometrics: An Empiricist's Companion. Princeton, NJ: Princeton University Press.

Angrist, Joshua D., and Alan B. Krueger. 2001. "Instrumental Variables and the Search for Identification: From Supply and Demand to Natural Experiments.” Journal of Economic Perspectives 15 (4): 69-85.

Bartik, Timothy J. 1991. Who Benefits from State and Local Economic Development Policies? Kalamazoo, MI: W. E. Upjohn Institute.

Baum-Snow, Nathaniel. 2007. “Did Highways Cause Suburbanization?” Quarterly Journal of Economics 122 (2): 775-805.

Bingham, Richard D. 1975. Public Housing and Urban Renewal: An Analysis of Federal-Local Relations. New York, NY: Praeger Publishers.

Bound, John, David Jaeger, and Regina Baker. 1995. "Problems with Instrumental Variables Estimation when the Correlation Between the Instruments and the Endogenous Explanatory Variable Is Weak.” Journal of the American Statistical Association 90 (430): 443-450.

Boustan, Leah Platt. 2010. "Was Postwar Suburbanization White Flight? Evidence from the Black Migration.” Quarterly Journal of Economics 125 (1): 417-443.

Brueckner, Jan K., and Robert W. Helsley. 2011. “Sprawl and Blight.” Journal of Urban Economics 69 (2): 205-213.

Carey, Bill. 2001. “A City Swept Clean: How Urban Renewal, for Better and for Worse, Created the City We Know Today.” Nashville Scene, September 6. http://www.nashvillescene.com/nashville/a-city-swept-clean/Content?oid=1186025.

Congressional Quarterly. 1949. Congressional Quarterly Almanac: $81^{\text {st }}$ Congress, $1^{\text {st }}$ Session- 
1949, Vol. V. Washington, DC: Congressional Quarterly News Features.

Conley, Timothy G., Christian B. Hansen, and Peter E. Rossi. 2012. "Plausibly Exogenous.” Review of Economics and Statistics 94 (1): 260-272.

Council of State Governments. 1948-49 to 1960-61. The Book of the States. Lexington, KY: Council of State Governments.

Cullen, Julie Berry, and Steven D. Levitt. 1999. “Crime, Urban Flight, and the Consequences for Cities.” Review of Economics and Statistics 81 (2): 159-169.

Davis, Otto A., and Andrew B. Whinston. 1961. “The Economics of Urban Renewal.” Law and Contemporary Problems 26 (1): 105-117.

Fairbanks, Robert B. 2002. “The Texas Exception: San Antonio and Urban Renewal, 19491965.” Journal of Planning History 1 (2): 181-196.

Fairbanks, Robert B. 2006. "The Failure of Urban Renewal in the Southwest: From City Needs to Individual Rights.” Western Historical Quarterly 37 (3): 303-325.

Federal Housing Administration. 1941. A Handbook on Urban Redevelopment for Cities in the United States. Washington, DC: GPO.

Field, Erica, and Michael Kremer. 2005. "Impact Evaluation for Slum Upgrading Interventions.” Washington, DC: World Bank.

Foard, Ashley A., and Hilbert Fefferman. 1960. "Federal Urban Renewal Legislation.” Law and Contemporary Problems 25 (4): 635-684.

Fogelson, Robert M. 2001. Downtown: Its Rise and Fall, 1880-1950. New Haven, CT: Yale University Press.

Forman, William H., Jr. 1969. “The Conflict over Federal Urban Renewal Enabling Legislation in Louisiana." Louisiana Studies 8: 251-267.

Galster, George, Christopher Walker, Christopher Hayes, Patrick Boxall, and Jennifer Johnson. 2004. "Measuring the Impact of Community Development Block Grant Spending on Urban Neighborhoods.” Housing Policy Debate 15 (4): 903-934.

Gans, Herbert J. 1965. “The Failure of Urban Renewal.” Commentary (July): 29-37.

Gelfand, Mark I. 1975. A Nation of Cities: The Federal Government and Urban America, 19331965. New York, NY: Oxford University Press.

Germany, Kent B. 2007. New Orleans After the Promises: Poverty, Citizenship, and the Search for the Great Society. Athens, GA: University of Georgia Press. 
Glaeser, Edward L., and Joshua D. Gottlieb. 2008. “The Economics of Place-Making Policies.” Brookings Papers on Economic Activity 39 (1): 155-239.

Glaeser, Edward L., and Joshua D. Gottlieb. 2009. "The Wealth of Cities: Agglomeration Economies and Spatial Equilibrium in the United States.” Journal of Economic Literature 47 (4): 983-1028.

Glaeser, Edward L., and Kristina Tobio. 2008. “The Rise of the Sunbelt.” Southern Economic Journal 74 (3): 610-643.

Gotham, Kevin Fox. 2001. “Urban Redevelopment, Past and Present.” In Critical Perspectives on Urban Redevelopment, ed. Kevin Fox Gotham, 1-31. Amsterdam: Elsevier Science.

Graham, Cole Blease, Jr. 2007. The South Carolina Constitution: A Reference Guide. Westport, CT: Praeger.

Greenstone, Michael, Richard Hornbeck, and Enrico Moretti. 2010. "Identifying Agglomeration Spillovers: Evidence from Million Dollar Plants.” Journal of Political Economy 118 (3): 536598.

Greenstone, Michael, and Enrico Moretti. 2004. "Bidding for Industrial Plants: Does Winning a ‘Million Dollar Plant” Increase Welfare?” MIT Department of Economics Working Paper 0439.

Greer, Guy, and Alvin H. Hansen. 1941. Urban Redevelopment and Housing: A Program for Post-War. Washington, DC: National Planning Association.

Groberg, Robert P. 1965. “Urban Renewal Realistically Reappraised.” Law and Contemporary Problems 30 (1): 212-229.

Groberg, Robert P. 1968. “Evolution of the Federal Urban Renewal Program.” Research Report \#20, National Commission on Urban Problems. Washington, DC: unpublished.

Guandolo, Joseph. 1956. “Housing Codes in Urban Renewal.” George Washington Law Review 25 (1): 1-52.

Haines, Michael R. and the Inter-university Consortium for Political and Social Research (ICPSR). 2004. "Historical, Demographic, Economic, and Social Data: The United States, 1790-2000.” [Computer file]. ICPSR02896-v2. Hamilton, NY: Colgate University/Ann Arbor, MI: ICPSR [producers]. Ann Arbor, MI: ICPSR [distributor], 2005-04-29. doi:10.3886/ICPSR02896.

Hornbeck, Richard, and Dan Keniston. 2011. “Creative Destruction: Barriers to Urban Growth 
Illuminated by $19^{\text {th }}$ Century Great Fires.” Unpublished.

Ioannides, Yannis M. 2002. “Residential Neighborhood Effects.” Regional Science \& Urban Economics 32 (2): 145-165.

Jacobs, Jane. 1993 [1961]. The Death and Life of Great American Cities. New York, NY: The Modern Library.

Johnson, Nina, and Jeffrey Tashman. 2002. “Urban Renewal in Oregon.” Portland, OR: Tashman Johnson LLC.

Lang, Robert E., and Rebecca R. Sohmer. 2000. “Legacy of the Housing Act of 1949.” Housing Policy Debate 11 (2): 291-297.

Leip, David. 2009. “Dave Leip’s Atlas of US Presidential Elections.” Electronic database: http://uselectionatlas.org/ (accessed November 18, 2008).

Moretti, Enrico. 2011. “Local Labor Markets.” In Handbook of Labor Economics, Vol. 4B, edited by Orley Ashenfelter and David Card, 1237-1313. Amsterdam: North Holland.

Mukhija, Vinit. 2001. “Upgrading Housing Settlements in Developing Countries: The Impact of Existing Physical Conditions.” Cities 18 (4): 213-222.

National Association of Housing and Redevelopment Officials. 1951 to 1974. Journal of Housing. Washington, DC: National Association of Housing and Redevelopment Officials. Plott, Charles R. 1968. “Some Organizational Influences on Urban Renewal Decisions.” American Economic Review 58 (2): 306-321.

Porter, John Sherman. 1950. Moody's Manual of Investments, American and Foreign: Government Securities. New York, NY: Moody’s Investors Service.

Priemus, Hugo, and Gerard Metselaar. 1993. “Urban Renewal Policy in a European Perspective.” Netherlands Journal of Housing and the Built Environment 8 (4): 447-470.

Pritchett, Wendell E. 2003. “The ‘Public Menace’ of Blight: Urban Renewal and the Private Uses of Eminent Domain.” Yale Law \& Policy Review 21 (1): 1-52.

Ranney, Austin. 1965. "Parties in States Politics.” In Politics in the American States: A Comparative Analysis, edited by Herbert Jacob and Kenneth N. Vines, 61-99. Boston, MA: Little, Brown and Company.

Roback, Jennifer. 1980. The Value of Local Urban Amenities: Theory and Measurement. Unpublished Ph.D. Dissertation. Rochester, NY: University of Rochester.

Roback, Jennifer. 1982. “Wages, Rents, and the Quality of Life.” Journal of Political Economy 
90 (6): $1257-1278$.

Rosen, Sherwin. 1979. “Wages-based Indexes of Urban Quality of Life.” In Current Issues in Urban Economics, edited by Peter M. Mieszkowski and Mahlon R. Straszheim. Baltimore, MD: Johns Hopkins University Press.

Rossi-Hansberg, Esteban, Pierre-Daniel Sarte, and Raymond Owens III. 2010. "Housing Externalities.” Journal of Political Economy 118 (3): 485-535.

Rothenberg, Jerome. 1967. Economic Evaluation of Urban Renewal: Conceptual Foundation of Benefit-Cost Analysis. Washington, DC: Brookings Institution.

Ruggles, Steven, Matthew Sobek, Trent Alexander, Catherine A. Fitch, Ronald Goeken, Patricia Kelly Hall, Miriam King, and Chad Ronnander. 2008. Integrated Public Use Microdata Series: Version 4.0. Minneapolis, MN: Minnesota Population Center (accessed May 4, 2008).

Schall, Lawrence D. 1976. “Urban Renewal Policy and Economic Efficiency.” American Economic Review 66 (4): 612-628.

Slayton, William L. 1966. "The Operation and Achievements of the Urban Renewal Program.” In Urban Renewal: The Record and the Controversy, edited by James Q. Wilson, 189-229. Cambridge, MA: MIT Press.

Sogg, Wilton, and Warren Wertheimer. 1966. "Legal and Governmental issues in Urban Renewal.” In Urban Renewal: The Record and the Controversy, edited by James Q. Wilson, 126-188. Cambridge, MA: MIT Press.

Somin, Ilya. 2009. “The Limits of Backlash: Assessing the Political Response to Kelo.” Minnesota Law Review 93 (6): 2100-2178.

Staiger, Douglas, and James H. Stock. 1997. "Instrumental Variables Regressions with Weak Instruments.” Econometrica 65 (3): 557-586.

Stock, James H., Jonathan H. Wright, and Motohiro Yogo. 2002. “A Survey of Weak Instruments and Weak Identification in Generalized Method of Moments.” Journal of Business \& Economic Statistics 20 (4): 518-529.

Straits, Bruce C. 1965. “Community Adoption and Implementation of Urban Renewal.” American Journal of Sociology 71 (1): 77-82.

Teaford, Jon C. 1990. The Rough Road to Renaissance: Urban Revitalization in America, 19401985. Baltimore, MD: Johns Hopkins University Press.

Teaford, Jon C. 2000. “Urban Renewal and Its Aftermath.” Housing Policy Debate 11 (2): 443- 
465.

United States Department of Commerce, Bureau of the Census. 1953. Census of Population: 1950, Volume II. Washington, DC: U.S. Government Printing Office.

United States Department of Commerce, Bureau of the Census. 1954a. Census of Housing: 1950, Vol. II. Washington, DC: U.S. Government Printing Office.

United States Department of Commerce, Bureau of the Census. 1954b. State Payments to Local Governments in 1952. State and Local Government Special Studies. Washington, DC: U.S. Government Printing Office.

United States Department of Commerce, Census Bureau. 2002. 2000 Census of Population and Housing. American Fact Finder. factfinder2.census.gov/ (accessed September 16, 2010). United States Department of Housing and Urban Development. 1974a. Statistical Yearbook. Washington, DC: U.S. Government Printing Office.

United States Department of Housing and Urban Development. 1974b. Urban Renewal Directory: June 30, 1974. Washington, DC: HUD.

United States Department of Housing and Urban Development. 1966. Urban Renewal Project Characteristics: June 30, 1966. Washington, DC: HUD.

United States Housing and Home Finance Agency, Office of the General Counsel. 1958. "State Enabling Legislation, Urban Renewal, and Urban Renewal.” Washington, DC: HHFA. United States Housing and Home Finance Agency, Office of the General Counsel. 1962. "State Enabling Legislation, Urban Redevelopment, and Urban Renewal.” Washington, DC: HHFA. von Hoffman, Alexander. 2000. "A Study in Contradictions: The Origins and Legacy of the Housing Act of 1949.” Housing Policy Debate 11 (2): 299-329.

White, Michael J. 1980. Urban Renewal and the Changing Residential Structure of the City. Chicago, IL: Community and Family Study Center at the University of Chicago.

Williams, John B., Paul D. Chapman, Louis G. Milan, and Donald T. Knutson. 1973.

“Myths/Realities of Urban Renewal.” Journal of Housing 4: 170-178.

Wilson, James Q. 1966. Urban Renewal: The Record and the Controversy. Cambridge, MA: MIT Press.

Wines, Michael, and Jonathan Ansfield. 2010. “Trampled in a Land Rush, Chinese Push Back.” The New York Times, May 27. http:/www.nytimes.com/2010/05/27/world/asia/27china.html Zhang, Yan, and Ke Fang. 2004. “Is History Repeating Itself? From Urban Renewal in the 
United States to Inner-City Redevelopment in China.” Journal of Planning Education and Research 23: 286-298. 


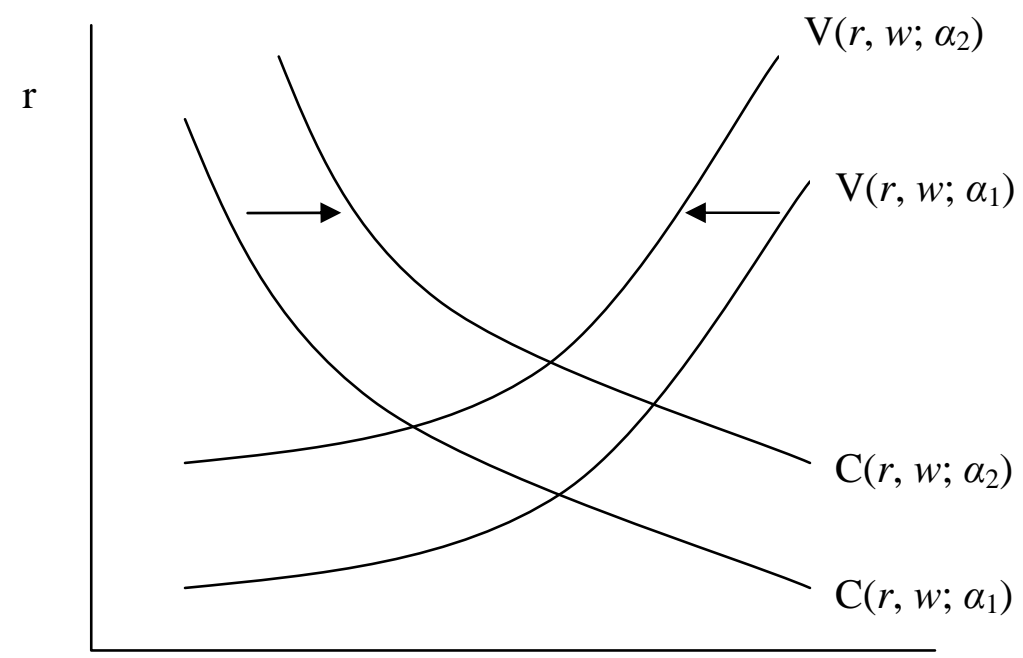

W

Figure 1: Improvement in a "Productive Amenity"

Notes: A rise in amenities that both consumers and producers value tends to raise the rental value of land $(r)$ and have an ambiguous effect on wages (w), as in Roback (1980). The amenity level is denoted by $\alpha$, and $\alpha_{1}<\alpha_{2}$. See text for more discussion. 
Panel A: Added-Variable Plot for Cities

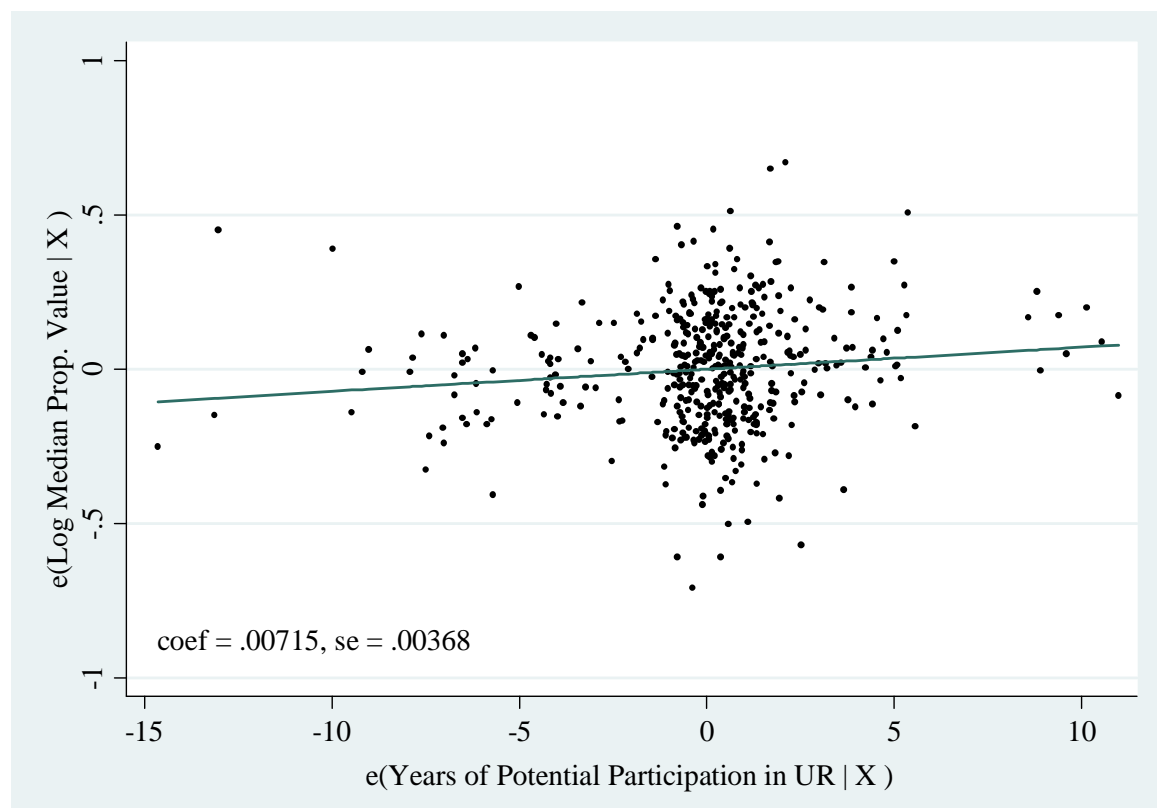

Panel B: Added-Variable Plot for Rural Counties

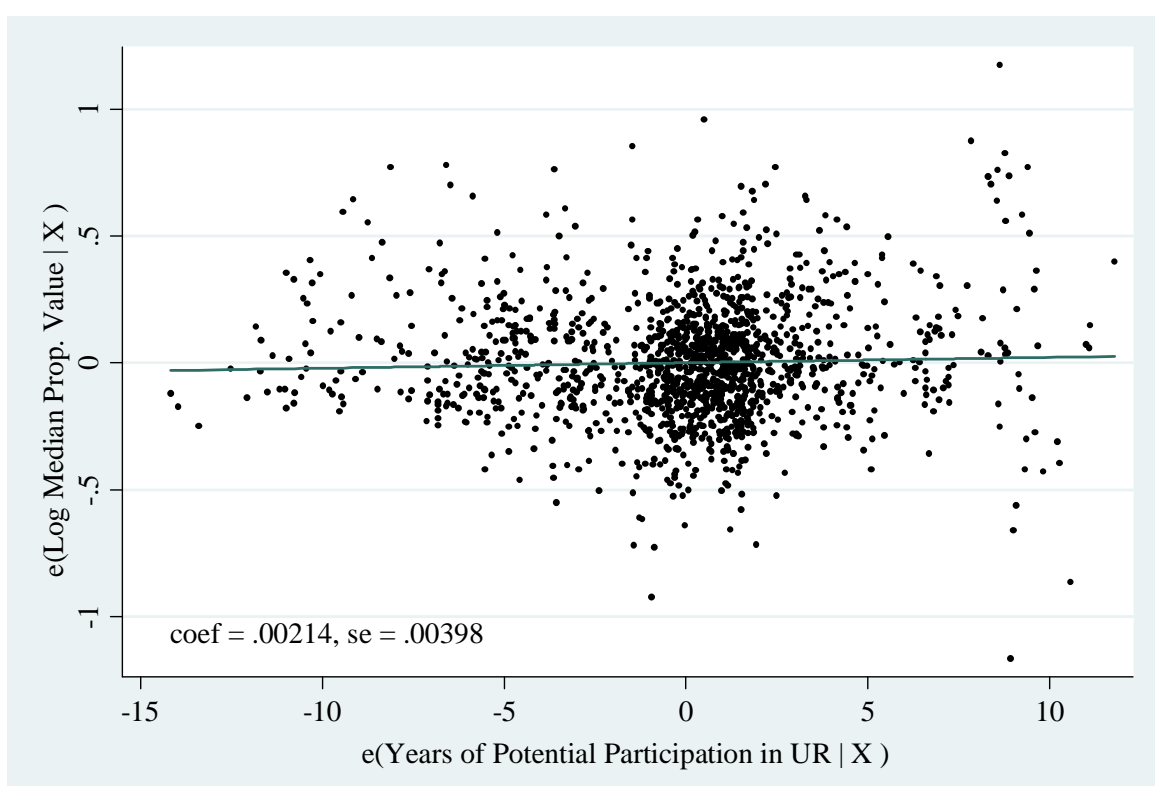

Figure 2: Log Median Property Value in 1980 and Potential Urban Renewal Participation

Notes: Each regression includes controls for observable local characteristics in 1950 (described in text) and census division fixed effects. The results correspond to row 1 and 2 of column 1 in Table 2. 
Table 1: Urban Renewal Funding and Enabling Legislation

\begin{tabular}{|c|c|c|}
\hline \multirow{2}{*}{ Years of potential UR participation } & 1 & 2 \\
\hline & $\begin{array}{l}9.706 \\
(2.670)\end{array}$ & $\begin{array}{l}10.320 \\
(2.779)\end{array}$ \\
\hline Percent units owner-occupied 1950 & ---- & $\begin{array}{l}-2.237 \\
(1.592)\end{array}$ \\
\hline Ln median property value 1950 & ----- & $\begin{array}{c}-66.937 \\
(106.261)\end{array}$ \\
\hline Percent units dilapidated 1950 & ----- & $\begin{array}{c}1.047 \\
(3.229)\end{array}$ \\
\hline Percent units built before 1920 & ----- & $\begin{array}{l}-0.155 \\
(1.116)\end{array}$ \\
\hline Percent units w/o full plumbing 1950 & ----- & $\begin{array}{l}-0.480 \\
(1.632)\end{array}$ \\
\hline Percent units crowded 1950 & ----- & $\begin{array}{l}-0.063 \\
(2.397)\end{array}$ \\
\hline Ln population 1950 & ----- & $\begin{array}{c}-3.723 \\
(15.609)\end{array}$ \\
\hline Percent population nonwhite 1950 & ----- & $\begin{array}{l}1.542 \\
(1.457)\end{array}$ \\
\hline \multicolumn{3}{|l|}{ Percent employment in manufacturing } \\
\hline 1950 & ----- & $\begin{array}{l}-1.141 \\
(1.614)\end{array}$ \\
\hline Percent labor force employed 1950 & ----- & $\begin{array}{l}-11.024 \\
(7.307)\end{array}$ \\
\hline Median years schooling 1950 & ----- & $\begin{array}{c}4.292 \\
(24.582)\end{array}$ \\
\hline Ln median family income 1950 & ----- & $\begin{array}{c}-13.665 \\
(211.642)\end{array}$ \\
\hline Percent families w/ income $<\$ 2 \mathrm{k} 1950$ & ----- & $\begin{array}{l}-1.165 \\
(4.778)\end{array}$ \\
\hline Census-division dummies & Yes & Yes \\
\hline Observations & 458 & 458 \\
\hline R-squared & 0.103 & 0.135 \\
\hline
\end{tabular}

Notes: The dependent variable is cumulative Title I grant approvals per capita at the city-level between 1949 and 1974. Heteroskedasticity-robust standard errors corrected for correlation within states are reported in parentheses. A "dilapidated" unit had "serious deficiencies, was rundown or neglected, or was of inadequate original construction, so that it did not provide adequate shelter or protection against the elements or endangered the safety of the occupants.... was below the generally accepted minimum standard for housing and should be torn down or extensively repaired or rebuilt" (U.S. Department of Commerce, 1954a, volume II, part 1, XIV). Units without full plumbing are those without "complete plumbing for exclusive use." "Crowded" units are those with more than 1 person per room. Median property value pertains to owner-occupied housing. Summary statistics are in Appendix Table A1.

Sources: See Appendix. 
Table 2: Comparison of City and Rural-County Outcomes, Reduced-form Regressions of Outcomes on Instrumental Variable

\begin{tabular}{lccccc}
\hline & $\begin{array}{c}\text { Ln } \\
\text { median } \\
\text { property } \\
\text { value }\end{array}$ & $\begin{array}{c}\text { Ln } \\
\text { median } \\
\text { family } \\
\text { income }\end{array}$ & $\begin{array}{c}\text { Employment } \\
\text { rate }\end{array}$ & $\begin{array}{c}\text { Poverty } \\
\text { rate }\end{array}$ & $\begin{array}{c}\text { Ln } \\
\text { population }\end{array}$ \\
\hline $\begin{array}{l}\text { 1. Sample of cities, } \\
\begin{array}{l}\text { IV based on year of } \\
\text { enabling legislation }\end{array}\end{array}$ & $\begin{array}{c}0.00715 \\
(0.00368)\end{array}$ & $\begin{array}{c}0.00249 \\
(0.00114)\end{array}$ & $\begin{array}{c}0.0347 \\
(0.0213)\end{array}$ & $\begin{array}{c}-0.0630 \\
(0.0547)\end{array}$ & $\begin{array}{c}0.00936 \\
(0.00551)\end{array}$ \\
$\begin{array}{l}\text { 2. Sample of rural } \\
\text { counties, }\end{array}$ & 0.00214 & -0.000718 & 0.00117 & -0.00838 & -0.00271 \\
$\begin{array}{l}\text { IV based on earliest year } \\
\text { of state enabling }\end{array}$ & $(0.00398)$ & $(0.00164)$ & $(0.0536)$ & $(0.0441)$ & $(0.00471)$ \\
legislation & & & & & \\
$\begin{array}{l}\text { 3. Sample of rural } \\
\text { counties, }\end{array}$ & 0.000112 & -0.000545 & -0.0170 & -0.00155 & -0.00488 \\
$\begin{array}{l}\text { IV based on latest year of } \\
\text { state enabling legislation }\end{array}$ & $(0.00325)$ & $(0.00139)$ & $(0.0344)$ & $(0.0384)$ & $(0.00397)$ \\
& & & & & \\
\hline
\end{tabular}

Notes: Each coefficient is from a separate OLS regression of an economic outcome on years of eligibility for urban renewal (based on the timing of state enabling legislation) and control variables. Row 1's sample includes the cities examined in Table 1. Rows 2 and 3 include rural counties (less than or equal to 25 percent urban population in 1950, approximately half of all U.S. counties). The underlying control variables for the city and county regressions are very similar but not exactly the same due to data availability in Haines (2004). Differences are as follows: whereas the city regressions control for proportion of housing units built before 1920 (and counted in 1950), the county regressions control for the proportion of units built between 1940 and 1950 (and counted in 1950); whereas the city regressions control separately for the proportion of units without full plumbing and the proportion of units dilapidated, the county regressions control for the proportion with full plumbing and not dilapidated (a single variable); and whereas the city regressions control for the proportion of units with more than 1 person per room, the county regressions control for median number of rooms per unit and median number of persons per unit. Standard errors are clustered by state.

Sources: See Appendix. 
Table 3: Urban Renewal Effects on Property Value, Income, Employment, and Poverty

\begin{tabular}{|c|c|c|c|c|}
\hline & $\begin{array}{l}\text { Ln median } \\
\text { property } \\
\text { value }\end{array}$ & $\begin{array}{l}\text { Ln median } \\
\text { family } \\
\text { income }\end{array}$ & $\begin{array}{l}\text { Employme } \\
\text { nt rate }\end{array}$ & $\begin{array}{l}\text { Poverty } \\
\text { rate }\end{array}$ \\
\hline Panel A: Basic specification & & & & \\
\hline $\begin{array}{l}\text { 1: Controls for } 1950 \text { characteristics, census } \\
\text { division }\end{array}$ & $\begin{array}{c}0.000690 \\
(0.000345)\end{array}$ & $\begin{array}{c}0.000241 \\
(0.000110)\end{array}$ & $\begin{array}{c}0.00337 \\
(0.00203)\end{array}$ & $\begin{array}{l}-0.00611 \\
(0.00508)\end{array}$ \\
\hline Panel B: Additional controls & & & & \\
\hline $\begin{array}{l}\text { 2: Add controls for public housing, poverty } \\
\text { spending, Model Cities }\end{array}$ & $\begin{array}{c}0.000992 \\
(0.000506)\end{array}$ & $\begin{array}{c}0.000413 \\
(0.000208)\end{array}$ & $\begin{array}{c}0.00610 \\
(0.00307)\end{array}$ & $\begin{array}{c}-0.0127 \\
(0.00916)\end{array}$ \\
\hline $\begin{array}{l}\text { 3: Add controls for state aid to cities and } \\
\text { support for Goldwater }\end{array}$ & $\begin{array}{c}0.001000 \\
(0.000383)\end{array}$ & $\begin{array}{c}0.000278 \\
(0.000137)\end{array}$ & $\begin{array}{c}0.00741 \\
(0.00377)\end{array}$ & $\begin{array}{l}-0.00935 \\
(0.00626)\end{array}$ \\
\hline $\begin{array}{l}\text { 4: Add controls for labor-demand shift (based } \\
\text { on industrial composition) and mean January } \\
\text { temperature }\end{array}$ & $\begin{array}{c}0.000695 \\
(0.000338)\end{array}$ & $\begin{array}{c}0.000265 \\
(0.000119)\end{array}$ & $\begin{array}{c}0.00407 \\
(0.00233)\end{array}$ & $\begin{array}{l}-0.00785 \\
(0.00471)\end{array}$ \\
\hline 5: Drop largest city in each state & $\begin{array}{c}0.000599 \\
(0.000331)\end{array}$ & $\begin{array}{c}0.000245 \\
(0.000098)\end{array}$ & $\begin{array}{c}0.00356 \\
(0.00182)\end{array}$ & $\begin{array}{l}-0.00691 \\
(0.00461)\end{array}$ \\
\hline $\begin{array}{l}\text { Panel C: Changing instruments } \\
\text { 6: Alternative legal coding, earliest year of } \\
\text { enabling leg. }\end{array}$ & $\begin{array}{c}0.000789 \\
(0.000445)\end{array}$ & $\begin{array}{c}0.000318 \\
(0.000130)\end{array}$ & $\begin{array}{c}0.00514 \\
(0.00266)\end{array}$ & $\begin{array}{r}-0.00896 \\
(0.00615)\end{array}$ \\
\hline $\begin{array}{l}\text { 7: Alternative legal coding, latest year of } \\
\text { enabling leg. }\end{array}$ & $\begin{array}{c}0.000710 \\
(0.000395)\end{array}$ & $\begin{array}{c}0.000307 \\
(0.000110)\end{array}$ & $\begin{array}{c}0.00459 \\
(0.00234)\end{array}$ & $\begin{array}{l}-0.00762 \\
(0.00501)\end{array}$ \\
\hline $\begin{array}{l}\text { 8: State supreme court reversal of enabling } \\
\text { legislation }\end{array}$ & $\begin{array}{c}0.000852 \\
(0.000384)\end{array}$ & $\begin{array}{c}0.000252 \\
(0.000097)\end{array}$ & $\begin{array}{c}0.00598 \\
(0.00314)\end{array}$ & $\begin{array}{l}-0.00760 \\
(0.00497)\end{array}$ \\
\hline
\end{tabular}

Notes: The top entry of each cell is the estimated coefficient on urban renewal funding per capita from a separate instrumental variable regression. Heteroskedasticity-robust standard errors are adjusted for correlation within states and reported in parentheses below the coefficient. See Table 1 's notes for variable definitions.

Sources: See Appendix. 
Table 4: Urban Renewal Effects between 1950 and 1980,

Reduced-Form Regressions of Outcomes on Instrumental Variable

\begin{tabular}{lcccc}
\hline & $\begin{array}{c}\text { Ln median } \\
\text { property } \\
\text { value }\end{array}$ & $\begin{array}{c}\text { Ln median } \\
\text { family } \\
\text { income }\end{array}$ & $\begin{array}{c}\text { Employment } \\
\text { rate }\end{array}$ & $\begin{array}{c}\text { Poverty rate } \\
\text { (or under } \\
\$ 3,000 \text { in } \\
1960)\end{array}$ \\
\hline 1980 outcomes & 0.00720 & 0.00223 & 0.0320 & -0.0627 \\
& $(0.00363)$ & $(0.00125)$ & $(0.0208)$ & $(0.0553)$ \\
1970 outcomes & 0.00585 & 0.00335 & 0.0591 & -0.109 \\
& $(0.00301)$ & $(0.000954)$ & $(0.0195)$ & $(0.0356)$ \\
1960 outcomes & 0.000299 & 0.00222 & 0.0454 & -0.0415 \\
& $(0.00293)$ & $(0.000994)$ & $(0.0233)$ & $(0.0467)$ \\
\hline
\end{tabular}

Notes and sources: The regression specification is described by equation (3) in the paper. All regressions control for 1950 city-level characteristics $\left(\mathbf{X}_{i j t}\right)$, including the 1950 value of the outcome variable, and census-division-by-time fixed effects. Each column reports the estimates of $\pi_{1 \mathrm{t}}$ from a separate regression. In 1960, the poverty rate had not been defined, and so we use the proportion of families with income less than $\$ 3,000$ (1960 dollars). A balanced panel is used, leading to small differences in the 1980 row relative to results in Table 2. Standard errors are clustered by state. 
Table 5: Urban Renewal Effects on Population and Housing Characteristics

\begin{tabular}{|c|c|c|c|c|c|c|}
\hline & $\begin{array}{l}\text { Median } \\
\text { schooling }\end{array}$ & $\begin{array}{l}\text { Percentage } \\
\text { black }\end{array}$ & $\begin{array}{c}\text { Ln } \\
\text { population }\end{array}$ & $\begin{array}{l}\text { Ln housing } \\
\text { units }\end{array}$ & $\begin{array}{l}\text { Percentage } \\
\text { old units }\end{array}$ & $\begin{array}{l}\text { Percentage } \\
\text { units } \\
\text { without all } \\
\text { plumbing }\end{array}$ \\
\hline $\begin{array}{l}\text { Panel A: Basic specification } \\
\text { 1: Controls for } 1950 \\
\text { characteristics, census } \\
\text { division }\end{array}$ & $\begin{array}{l}0.00000427 \\
(0.000434)\end{array}$ & $\begin{array}{c}0.0112 \\
(0.00998)\end{array}$ & $\begin{array}{c}0.000916 \\
(0.000543)\end{array}$ & $\begin{array}{c}0.00108 \\
(0.000537)\end{array}$ & $\begin{array}{l}-0.0330 \\
(0.0130)\end{array}$ & $\begin{array}{l}-0.00172 \\
(0.00119)\end{array}$ \\
\hline $\begin{array}{l}\text { Panel B: Additional controls } \\
\text { 2: Add controls for public } \\
\text { housing, poverty spending, } \\
\text { Model Cities }\end{array}$ & $\begin{array}{l}0.000197 \\
(0.000564)\end{array}$ & $\begin{array}{l}0.00202 \\
(0.0133)\end{array}$ & $\begin{array}{c}0.00137 \\
(0.000707)\end{array}$ & $\begin{array}{c}0.00155 \\
(0.000736)\end{array}$ & $\begin{array}{l}-0.0390 \\
(0.0166)\end{array}$ & $\begin{array}{l}-0.00216 \\
(0.00147)\end{array}$ \\
\hline $\begin{array}{l}\text { 3: Add controls for state } \\
\text { aid to cities and support } \\
\text { for Goldwater }\end{array}$ & $\begin{array}{c}0.000132 \\
(0.000394)\end{array}$ & $\begin{array}{c}0.00563 \\
(0.00983)\end{array}$ & $\begin{array}{c}0.00110 \\
(0.000548)\end{array}$ & $\begin{array}{c}0.00123 \\
(0.000545)\end{array}$ & $\begin{array}{l}-0.0411 \\
(0.0156)\end{array}$ & $\begin{array}{l}-0.00164 \\
(0.00117)\end{array}$ \\
\hline $\begin{array}{l}\text { 4: Add control for labor- } \\
\text { demand shift and January } \\
\text { temperature }\end{array}$ & $\begin{array}{l}0.0000780 \\
(0.000394)\end{array}$ & $\begin{array}{c}0.00755 \\
(0.00876)\end{array}$ & $\begin{array}{c}0.000844 \\
(0.000457)\end{array}$ & $\begin{array}{c}0.00103 \\
(0.000489)\end{array}$ & $\begin{array}{l}-0.0307 \\
(0.0113)\end{array}$ & $\begin{array}{l}-0.00179 \\
(0.00120)\end{array}$ \\
\hline $\begin{array}{l}\text { 5: Drop largest city in each } \\
\text { state }\end{array}$ & $\begin{array}{l}-0.0000310 \\
(0.000458)\end{array}$ & $\begin{array}{c}0.00419 \\
(0.00863)\end{array}$ & $\begin{array}{c}0.000718 \\
(0.000509)\end{array}$ & $\begin{array}{c}0.000836 \\
(0.000484)\end{array}$ & $\begin{array}{l}-0.0326 \\
(0.0136)\end{array}$ & $\begin{array}{l}-0.00159 \\
(0.00107)\end{array}$ \\
\hline $\begin{array}{l}\text { Panel C: Alternative instrum } \\
\text { 6: IV with alternative legal } \\
\text { coding, earliest year of } \\
\text { enabling leg. }\end{array}$ & $\begin{array}{l}\text { nents } \\
0.000103 \\
(0.000460)\end{array}$ & $\begin{array}{c}0.0120 \\
(0.0110)\end{array}$ & $\begin{array}{c}0.00118 \\
(0.000764)\end{array}$ & $\begin{array}{c}0.00137 \\
(0.000781)\end{array}$ & $\begin{array}{l}-0.0417 \\
(0.0167)\end{array}$ & $\begin{array}{l}-0.00116 \\
(0.00130)\end{array}$ \\
\hline $\begin{array}{l}\text { 7: IV with alternative legal } \\
\text { coding, latest year of } \\
\text { enabling leg. }\end{array}$ & $\begin{array}{c}0.000415 \\
(0.000454)\end{array}$ & $\begin{array}{c}0.0135 \\
(0.0114)\end{array}$ & $\begin{array}{c}0.000473 \\
(0.000644)\end{array}$ & $\begin{array}{c}0.000781 \\
(0.000652)\end{array}$ & $\begin{array}{l}-0.028901 \\
(0.014152)\end{array}$ & $\begin{array}{l}-0.00169 \\
(0.00119)\end{array}$ \\
\hline $\begin{array}{l}\text { 8: State court reversal of } \\
\text { enabling legislation }\end{array}$ & $\begin{array}{c}0.000683 \\
(0.000583)\end{array}$ & $\begin{array}{l}0.00749 \\
(0.0147)\end{array}$ & $\begin{array}{c}0.000428 \\
(0.000637)\end{array}$ & $\begin{array}{c}0.000769 \\
(0.000613)\end{array}$ & $\begin{array}{l}-0.00969 \\
(0.0160)\end{array}$ & $\begin{array}{l}0.000316 \\
(0.00189)\end{array}$ \\
\hline
\end{tabular}

Notes: Each cell reports the coefficient estimate on urban renewal funding per capita from a separate IV regression. Heteroskedasticity-robust standard errors are adjusted for correlation within states and reported in parentheses.

Sources: See Appendix. 
Table 6: Regressions including Controls for Potentially Endogenous Population Characteristics

\begin{tabular}{|c|c|c|c|c|}
\hline & $\begin{array}{l}\text { Ln median } \\
\text { property } \\
\text { value } \\
\end{array}$ & $\begin{array}{l}\text { Ln median } \\
\text { family } \\
\text { income } \\
\end{array}$ & $\begin{array}{l}\text { Employment } \\
\text { rate }\end{array}$ & Poverty rate \\
\hline 1: Basic specification & $\begin{array}{c}0.000690 \\
(0.000345)\end{array}$ & $\begin{array}{c}0.000241 \\
(0.000110)\end{array}$ & $\begin{array}{c}0.00337 \\
(0.00203)\end{array}$ & $\begin{array}{c}-0.00611 \\
(0.00508)\end{array}$ \\
\hline $\begin{array}{l}\text { 2: Basic specification plus } \\
\text { controls for percent black and } \\
\text { median education in } 1980\end{array}$ & $\begin{array}{c}0.000798 \\
(0.000364)\end{array}$ & $\begin{array}{c}0.000301 \\
(0.000120)\end{array}$ & $\begin{array}{c}0.00454 \\
(0.00230)\end{array}$ & $\begin{array}{c}-0.00861 \\
(0.00436)\end{array}$ \\
\hline
\end{tabular}

Notes and sources: See Table 3 and Appendix. Row 1 replicates the base specification results.

Row 2 adds controls for median education and percent black in 1980. Each coefficient is from a separate regression, and all standard errors are clustered by state. 